Eskişehir Osmangazi Üniversitesi iißBF Dergisi

Aralık 2019, C. 14, S. 3, $631-656$.

Başvuru : 30.10 .2018

Kabul : 02.01.2020

\title{
Ülkelerin Çevresel Performanslarının Çok Kriterli Karar Verme Yöntemleri ve Bulanık Mantık Tabanlı Bir Yaklaşım ile Bütünleşik Olarak Değerlendirilmesi
}

Enver Çakın ${ }^{1}$

Ejder Ayçin ${ }^{2}$

\begin{abstract}
Ülkelerin Çevresel Performanslarının Çok Kriterli Karar Verme Yöntemleri ve Bulanık Mantık Tabanlı Bir Yaklaşım İle Bütünleşik Olarak Değerlendirilmesi

Öz

Son yıllarda endüstrileşme, nüfus artışı, toplumun ihtiyaçlarının sürekli artması ve teknolojik gelişmeler nedeniyle ülkelerin çevresel sorunları gittikçe artmakta ve bu sorunu ortadan kaldırmak için ülkeler gerekli önlem ve tedbirleri almaktadır. Bu çalışmada çok kriterli karar verme (ÇKKV) yöntemlerinden Entropi, Gri iliş̧kisel Analiz (GIA) ve Oransal Analize Dayalı Çok Amaçılı Optimizasyon (MOORA) yöntemleri bütünleşik olarak kullanılarak ülkelerin çevresel performanslarını ölçen altı farklı çok kriterli karar verme modeli tanıtılmıştır. Entropi yöntemi ile kriter ağırlıkları hesaplanmış, GIA ve MOORA yöntemleri ile de ülkelerin çevresel performans düzeyleri analiz edilmiştir. Ayrıca altı farklı ÇKKV modelinden elde edilen sonuçlar bulanık mantık tabanlı bir yaklaşım ile birleştirilerek tek bir sonuca ulaşılmıştır. Analiz sonuçlarına göre, en önemli kriterlerin ormanlar, tarım ve su kaynakları olduğu, en iyi performans gösteren ülkelerin Avusturya, Danimarka ve Fransa olduğu sonucuna ulaşılmıştır.
\end{abstract}

Anahtar Kelimeler: Entropi, Gri İlişkisel Analiz, MOORA, Bulanık Mantık, Çevresel Performans Ölçümü.
The Evaluation of the Environmental Performance of the Countries with Multiple Criteria Decision Making Methods and A Fuzzy Logic Based Approach

\section{Abstract}

In recent years, due to industrialization, population growth, the continuous increase in the needs of the society and technological developments, the environmental problems of the countries are increasing and the countries take the necessary measures to eliminate this problem. In this study, six different multicriteria decision-making (MCDM) models that measure the environmental performance of countries using Entropy, Gray Relational Analysis (GRA) and Multi Objective Optimization on the basis of Ratio Analysis (MOORA) methods are introduced. Criteria weights are calculated by Entropy method and environmental performance levels of countries were analyzed by GRA and MOORA methods. In addition, the results obtained from six different MCDM models are combined with a fuzzy logic-based approach and a single result is achieved. According to the results of the analysis, it is concluded that the most important criteria are forests, agriculture, and water resources; the best performing countries are Austria, Denmark and France.

Keywords: Entropy, Grey Relation Analysis, MOORA, Fuzzy Logic, Measuring Environmental Performance.

\section{Giriş}

Ülkelerin sürdürülebilir kalkınmasındaki en önemli faktörlerden biri çevresel faktörlerdir. Doğal kaynaklarını etkin bir şekilde kullanan, çevresel kirlilikleri önleyen ve imha eden, çevre yönetimini planlı bir şekilde yaparak çevresel performanslarının güçlendiren ülkelerin gelecekte güçlü bir konumda olacakları söylenebilir. Ekonomik ve sosyal gelişmeler çevresel gelişmeler ile güçlendirilmedikçe ülkelerin sürdürülebilir bir kalkınmayı gerçekleştirmeleri mümkün değildir. Bu nedenle ülkeler ekonomik, siyasi, askeri ve sosyal sorunları ele almanın yanında çevresel sorunlarını da net bir şekilde belirleyerek gerekli önlemeleri almalı ve çözüm önerilerini hayata geçirmelidir.

\footnotetext{
${ }^{1}$ Dr. Enver Çakın, KOSGEB KOBi Uzmanı, İzmir Kuzey Müdürlüğü, E-posta: enver.cakin@kosgeb.gov.tr, Yazar ORCID bilgisi: orcid.org/0000-0001-7523-8193

2 Dr. Öğretim Üyesi, Kocaeli Üniversitesi IiBF, İşletme Bölümü, ejder.aycin@kocaeli.edu.tr, Yazar ORCID bilgisi: orcid.org/0000-0002-0153-8430
} 
İkinci Dünya savaşından sonra kitle üretimi artmış, üretimde kullanılan tüm hammaddeler ve doğal kaynaklar plansız bir şekilde tüketilmeye başlanmış ve üretim atıkları doğanın kirlenmesine neden olmuştur. 1970'li yıllardan itibaren artan çevre bilinci ile birlikte ülkeler gittikçe büyüyen çevre sorunlarını ortadan kaldırmak için çeşitli politikalar ve yöntemler geliştirmişlerdir. İnsanı odak noktasına alan, insan-çevre etkileşiminin dengeli bir şekilde oluşmasını sağlayan, çevresel kirliliği önleyici ve ekolojik sistemin güçlenmesini sağlayan politika ve araçlara ihtiyaç bulunmaktadır. Geliştirilen bu politikaların uygulamaya konulduktan sonra belirli dönemlerde performansların değerlendirilmesi ve zayıf olan noktaların güçlendirilmesi bir zorunluluktur. Ayrıca ülkeler diğer ülkelerin güçlü ve zayıf noktalarını tespit etmeli ve ülkeler birbirlerinin zayıf yönlerini güçlendirecek şekilde işbirliği ile sorunlarına çözüm aramalıdırlar. Çünkü çevresel sorunlar artık bölgesel olmaktan ziyade tüm ülkeleri ilgilendiren ve gündemlerinde olması gereken küresel bir sorun haline gelmeye başlamıştır. Küresel sorunların da ülkeler arasında işbirliği olmadan çözülebilmeleri çok zordur.

Performans değerlendirmesinde birçok yöntem kullanılmakla birlikte son yıllarda uygulamaları gittikçe artan ÇKKV yöntemleri ile etkin, basit ve tutarlı çözümler elde edilebilmektedir. Bu çalışmada ülkelerin çevresel performans değerlendirmesinde Entropi, GIA ve MOORA yöntemleri bütünleşik olarak kullanılmıştır. Entropi yönteminden kriterlerin ağırlıklarının belirlenmesi sürecinde, GiA ve MOORA yöntemlerinden ülkelerin çevresel performanslarının sıralanması sürecinde faydalanılmıştır. Entropi-GíA, Kriterleri Eşit Önem Ağırlıklı GiA, MOORA Oran Yaklaşımı, Entropi-MOORA Önem Katsayısı Yaklaşımı, Kriterleri Eşit Önem Ağırlıklı MOORA Referans Nokta Yaklaşımı, Entropi-MOORA Referans Nokta Yaklaşımı yöntemleri ile toplamda altı farklı ÇKKV karar modeli oluşturulmuştur. Tüm bu altı farklı modelin sonuçları birbirlerinden farklı olduğundan dolayı bu sonuçları ortak bir noktada birleştirmek için ise bulanık mantık tabanlı bir yöntem önerilmiştir. Hem kullanılan yöntemlerin diğer ÇKKV yöntemlerine nazaran daha az kullanılması hem de son aşamada geliştirilen bulanık mantık tabanlı bir çözüm önerisi ile farklı sonuçların birleştirilebileceği düşüncesi ile çalışmanın literatüre katkı sağlayacağı söylenebilir.

$\mathrm{Bu}$ düşünce ile çalışma dört bölümden oluşmaktadır. illk bölümde hem çevresel performansların değerlendirilmesinde kullanılan performans göstergeleri ve yöntemler hem de çalışmada kullanılan ÇKKV yöntemlerinin uygulamalarına ait literatür taramasına yer verilmiştir. İkinci bölümde çalışmada kullanılan yöntemlerin teorik olarak incelemeleri yapılmıştır. Üçüncü bölümde ise ÇKKV yöntemleri kullanılarak çevresel performans değerlendirilmesine ilişkin uygulama bölümüne yer verilmiştir. Son bölümde ise oluşturulan ÇKKV yöntemlerinin sonuçlarını birleştiren bulanık mantık tabanlı yeni bir yöntem ve uygulama sonuçları açıklanmıştır.

\section{Literatür Taraması}

Literatür incelendiğinde çevresel performansın ölçülmesinde farklı performans göstergelerinin geliştirildiği, teorik olarak yeni ölçüm modellerinin önerildiği, bu modellerin uygulamalarının yapıldığı, istatistiksel yöntemler, ÇKKV teknikleri ve yöneylem araştırması yöntemlerinin kullanıldığı çalışmalar gözlemlenmiştir. Metcalf vd. (1996), yaptıkları çalışmada çevresel performans ölçümü için teorik bir çerçeve geliştirmişler ve performans göstergelerini tanımlamışlardır. Çevresel performans ölçümü için çevresel uyum, personelin çevresel eğitimi, çevresel iyileştirmeler ve kirliliği önleme ana başlıkları altında 32 farklı çevresel performans göstergesi önermişlerdir. Hermann vd. (2006), yaptıkları çalışmada yaşam döngüsü analizi ve 
AHP yöntemlerini bütünleşik olarak kullanarak çevresel performansı değerlendiren bir model geliştirmişlerdir. Geliştirdikleri modeli Tayland'da hamur endüstrisinde uygulamışlardır. Tam vd. (2006), yaptıkları çalışmada inşaat sektöründe çevresel performans ölçümü göstergelerini belirlemişler ve bu göstergelerin önem derecelerini istatistiksel olarak analiz etmişlerdir. Anket tekniği ile 112 adet inşaat sektöründe faaliyet gösteren işletmeden topladıkları verileri analiz ederek çevresel performans göstergelerini mevzuata uygunluk, denetim faaliyetleri ve kaynak kullanımı olmak üzere 3 ana grupta toplam 9 alt değişkende incelemişlerdir. En önemli ana değişkeninin mevzuata uygunluk, en önemli alt değişkenin ise cezalar, şikayetler, uygunsuz muayene kayıtları, uygunsuzluk raporları ve marjinal vaka raporları olduğunu belirlemişlerdir.

Lundberg vd. (2009), yaptıkları çalışmada bir kamu kurumu için çevresel performans ölçüm amacıyla bir model ortaya koymuşlardır. Çalışmalarını İsveç Demiryolları kurumunda uygulamışlar ve çevresel performans ölçümü için bir teorik çerçeve geliştirmişlerdir. Performans ölçüm modelini geliştirirken baskı (pressure)-durum (state)-etki (response) modelini ve amaçlarla yönetim modelini kullanmışlardır. Performans göstergelerini km. başına enerji tüketimi ve emisyonu, gürültüden rahatsız olan insan sayısı, kirletilmiş bölge sayısı, ulaşım sisteminin ekolojiye etkisi ve ulaşım sisteminde kullanılan malzeme tüketimi olmak üzere 5 ana boyutta incelemişlerdir. Akıncı ve Akıncı (2010), yaptıkları çalışmada sürdürülebilir kalkınma için örgütlerin çevresel performanslarını ölçmede kullanılabilecek teknikleri ve dikkate alınacak performans göstergelerini teorik olarak analiz etmişlerdir. Dikkate alınacak performans göstergelerini kaynak kullanımı, atıklar ve diğer etkiler olmak üzere 3 ana sınıfta incelemişlerdir. Kaynak kullanımı ana değişkeninin altında hammadde, enerji ve su kullanımındaki azalma, atıklar ana değişkeni altında katı atık, toprak atıkları, havaya salınan atıklar gibi değişkenleri, diğer etkiler kapsamında ise ekolojik çevreye yapılan katkılar, biyolojik çeşitliliğe yapılan katkılar ve ozon tabakasının incelmesini önlemek için yapılan katkıları ele almışlardır. Performans ölçümü olarak çevresel etki matrisi, yaşam döngü analizi, yönetici tutum anketleri, puanlama yöntemi ve parametrik olmayan yöntemleri incelemişlerdir. Hsu ve Liu (2010), yaptıkları çalışmada Dengeli Puan Kartı yöntemiyle otomotiv sektöründe çevresel performansı değerlendirmişler ve Yapısal Eşitlik Modeli ile de çevresel performans göstergeleri arasındaki ilişkiyi incelemişlerdir. Araştırmaları sonucunda, çevresel performansı değerlendirmek ve çevresel stratejileri izlemek amacıyla çevresel strateji haritasını ortaya çıkarmışlardır. Djoundourian (2012), yaptığı çalışmada gelişen ülkelerin çevresel performanslarını karşılaştırmalı olarak incelemiş ve ANOVA testi ile bölgeler arasında farklııı olup olmadığını analiz etmiştir. Analizleri sonucunda bölgelere göre çevresel performansın değiştiği sonucuna ulaşmıştır. Chang (2013), yaptığı çalışmada Aylak Tabanlı VZA ile limanların çevresel etkinliklerini değerlendirmiştir. Girdi değişkenleri olarak işgücü, rıhtım uzunluğu, terminal alanı, enerji tüketimi, çıktı değişkenleri olarak da gemi sayısı, kargo elleçleme ve karbondioksit emisyonu değişkenlerini kullanmışlardır. Araştırma sonucunda, limanların ekonomik olarak etkin olmadığını ancak çevresel olarak etkin olduklarını belirtmiştir. Ismail vd. (2013), yaptıkları çalışmada petrol şirketlerinin çevresel performanslarını ve ekonomik etkinliklerini Veri Zarflama Analizi (VZA) ile analiz etmişler ve çevresel performans ile ekonomik etkinlik arasındaki ilişkiyi korelasyon analizi araştırmışlardır. Çevresel performans ölçümünde küresel ısınma potansiyeli indeksi, potansiyel asitleme denkliği, fotokimyasal ozon oluşturma potansiyeli, su kullanım indeksi ve deniz kıyılarını kirletme endeksi değişkenlerini, ekonomik etkinlik olarak varlıklar, çalışan sayısı ve gelir değişkenlerini kullanmışlardır. Analizleri sonucunda çevresel etkinlik ve ekonomik etkinlik arasında düşük ve pozitif yönde bir 
ilişki olduğunu ortaya koymuşlardır. Myhre vd. (2013), yaptıkları çalışmada çevresel performansın değerlendirilmesinde ve raporlanmasında çevresel performans göstergelerinin önemli bir araç olduğunu belirtmişler ve çevresel bilgi sistemi destekli olarak çevresel performans göstergelerini geliştirmişlerdir. Uygulamalarını Norveç Savunma Bakanlığında gerçekleştirmişler ve 2007-2010 dönemindeki çevresel performanslarını değerlendirmişlerdir. Çalışmaları ile çevresel indikatörlerin çevresel bilgi sistemi ile nasıl etkili bir şekilde bütünleştirileceğini ve çevresel konuların kamu hizmetlerinin performans ölçümüne nasıl entegre edileceğini göstermişlerdir.

Hourneaux Jr. (2014), yaptıkları çalışmada işletmeler için çevresel performansı ölçmenin zor bir süreç olduğunu ve bunun için doğru performans göstergelerini belirlemek gerektiğini açıklamışlardır. Anket tekniği ile sanayi işletmelerinin kullandıkları çevresel performans göstergelerini analiz ederek, uygulamalarını Brezilya'da faaliyet gösteren işletmelerde gerçekleştirmişlerdir. Analizleri sonucunda, direkt üretim maliyetleri ile ilişkili kullanılan çevresel performans göstergelerinin kullanımında büyük işletmeler ile küçük işletmeler arasında farklılık olduğu sonucuna ulaşmışlardır. Olafsson vd. (2014), yaptıkları çalışmada ülkelerin çevresel sürdürülebilirlik performansını ölçen teorik bir model geliştirmişlerdir ve İzlanda için modeli uygulamışlardır. Çevresel kırılganlık indeksi, çevresel performans indeksi, ekolojik ayak izi ve mutlu gezegen indeksi olmak üzere 4 değişkeni dikkate almışlardır. Abrahim (2015), yaptığı çalışmada VZA yaklaşımı ile Güneydoğu Asya ülkelerinin çevresel performanslarını ölçmüşlerdir. Çevresel performans değerlendirmenin bir ülkenin uzun dönemli sürdürülebilir büyümesinde etkili olan çevresel politikalarını dizayn etmek açısından önemli olduğunu belirtmiştir. Gelişmemiş ekonomilerin çevresel olarak etkin olduğunu, ekonomik etkinlik açısından ise güçlü ekonomiye sahip ülkelerin zayıf ekonomiye sahip ülkelerden daha etkin olduğu sonucuna ulaşmıştır. Campos vd. (2015), yaptıkları çalışmada Brezilya'nın güney bölgesindeki ISO 14001 yönetim sistemi belgeli işletmelerin çevresel performans değerlendirme ve izleme süreçlerinde kullandıkları çevresel performans göstergelerini incelemişlerdir. Faktör analizi ile performans göstergelerini gruplandırmışlar ve birçok işletmenin en önem verdiği kriterin yasal gereklilikler ile ilgili kriterler olduğunu vurgulamışlardır. Ayrıca kümeleme analizi ile sektörel olarak kullanılan çevresel performans göstergelerini incelemişlerdir. Garcia-Sanchez vd. (2015), yaptıkları çalışmada 5 ana faktör altında toplam 19 adet kriter kullanarak ülkelerin bütünleşik çevresel performans endeksini hesaplamışlardır. Öncelikle CRITIC yöntemi ile kriterleri ağırlıklandırmış ve basit toplamsal ağırıklandırma ile de ülkelerin 2004-2009 yılları arasındaki performans sıralamasını yapmışlardır. Analizleri sonucunda en önemli kriterlerin kentsel nüfus artışı, gübre kullanımı, tarımsal alan, korunan deniz kıyıları olduğu, performansı en iyi üç ülkenin İzlanda, Norveç ve İsveç, en kötü üç ülkenin ise Nijerya, Burundi ve Bangladeş olduğu sonuçlarına ulaşmışlardır. Liu vd. (2015), yaptıkları çalışmada Malmquist indeksi yaklaşımıyla eko-endüstri parklarının 2007-2010 yılları arasındaki çevresel performans düzeyi değişimlerini analiz etmişlerdir. Analizleri sonucunda, eko-endüstri parklarının kümülatif performans düzeylerinin önemli derecede iyileştirme gösterdiğini, yüksek teknoloji endüstri alanlarının ortalama eko-etkinlik düzeylerinin daha yüksek olduğu sonucuna ulaşmışlardır. Tanç ve Gümrah (2015), yaptıkları çalışmada sürdürülebilirlik kapsamında BIST'te imalat sanayi sektöründe faaliyet gösteren işletmelerin çevresel performanslarını TOPSIS yöntemiyle analiz etmişlerdir. Analizleri kapsamında geri dönüştürülen su miktarı, enerji tasarruf miktarı, emisyon azaltım miktarı, bertaraf edilen tehlikeli atık miktarı, bertaraf edilen tehlikesiz atık miktarı, çevre koruma ve harcama yatırım tutarı değişkenlerini dikkate almışlardır. Zadeh ve Kazemi (2016), yaptıkları 
çalışmada çevresel yönetim sistemi performans değerlendirme kriterlerini Bulanık AHP yöntemi ile ağırlıklandırmışlardır. Araştırma sonuçlarına göre; uygulama ve yönetme ana kriterinin en önemli kriter olduğu, bu kriteri planlama ve politika ana kriterlerinin takip ettiğini belirtmişlerdir. En önemli alt değişkenlerin ise risk yönetimi, üst düzey yönetim taahhüdü ve çevresel yönetim sisteminde çalışan farkındalığı olduğunu ortaya koymuşlardır.

Bimha ve Nhamo (2017), yaptıkları çalışmada 26 ülkeden 68 bankanın 2011-2014 yılları arasındaki çevresel performanslarını ölçmüşlerdir. Çevresel yönetim performansı ve çevresel operasyonel performansı olmak üzere iki ana değişkeni dikkate almışlardır. Çevresel yönetim performansı altında çevresel yönetişim, çevresel strateji, çevresel hedefler, çevre denetimi ve emisyon ticareti değişkelerini, çevresel operasyonel performans altında karbon emisyonu değişkenlerini ele alarak basit ortalama tekniği ile bankaların performanslarını ölçmüşlerdir. Ayrıca çoğu bankanın çevresel yönetim performansı ile çevresel operasyonel performansı arasında negatif korelasyon olduğu sonucuna ulaşmışlardır. Guo vd. (2017), yaptıkları çalışmada VZA ile Çin'deki 109 şehrin çevresel performansını değerlendirmişlerdir. Girdi değişkenleri olarak, toplam nüfus, çevresel yatırımları, toplam elektrik tüketimi ve kişi başına tüketim değişkenlerini, çıktı değişkenleri olarak da gayrisafi yurtiçi üretim, partiküler madde, kükürdioksit ve azotdioksit miktarlarını kullanmışlardır. Aksu ve Gencer (2018), yaptıkları çalışmada VZA ile OECD ülkelerinin çevre performansını incelemişlerdir. Çevre performans indeksi verilerini kullanarak hem CCR hem de süperetkinlik modeli ile 35 ülkenin performansını analiz etmişlerdir. Gök ve Yiğit (2017), yaptığı çalışmada Türkiye'deki 30 büyükşehrin sürdürülebilirlik performansını TOPSIS yöntemiyle incelemişlerdir. Ayrıca illerin stratejik amaçları ile sürdürülebilirlik boyutları arasındaki ilişkiyi araştırmışlardır. Nakıboğlu ve Bulğurcu (2017), yaptıkları çalışmada işletmelerin çevresel performans göstergelerini yeni bir ÇKKV yöntemi olan Modifiye Edilmiş Dijital Mantık yöntemi ile ağılıklandırmışlardır. Uzmanlar yardımıyla elde ettikleri sonuçlara göre, kullanılan geri dönüştürülmüş hammadde/malzeme miktarının tamamıyla yeni malzemeye oranı, ödenen çevre cezaları, çevre yönetim sistemi, çevre mevzuatlarına uyum ve toplam atık miktarı değişkenlerinin en önemli değişkenler olduğunu belirtmişlerdir. Zuo vd. (2017) yaptıkları çalışmada Çin'deki 30 şehrin 2006-2011 yılları arasındaki çevresel performanslarını değerlendirmişlerdir. Çevresel sağlık, çevre koruması, sürdürülebilir kaynak kullanımı ve çevresel yönetişim olmak üzere 4 ana grupta toplam 39 performans göstergesini dikkate alarak analizleri gerçekleştirmişlerdir. Öncelikle verileri normalize ederek belirledikleri kriter ağırlıkları ile alternatiflerin değerlerini çarparak şehirlerin performans değerlerini bulmuşlardır. Kümeleme analizi ile ülkeyi 3 ana bölgeye ayırarak, bölgelerin durumlarına göre çevresel politikalar konusunda öneriler sunmuşlardır.

Bu çalışmada Entropi yöntemi kriterlerin ağılıklandırılmasında, GiA ve MOORA yöntemleri de alternatiflerin sıralanması sürecinde kullanılmıştır. Çalışma kapsamında kullanılan bu ÇKKV tekniklerinin birçok farklı uygulamada da ele alındığı görülmektedir. Entropi yöntemi, herhangi bir uzmana ihtiyaç duymadan objektif bir şekilde kriterleri ağırlıklandırmaktadır. Lee vd. (2011) kurumsal kaynak planlama sistemi seçim sürecinde, Dashore vd. (2013) ürün değerlendirme sürecinde, Shahmardan ve Zadeh (2013) proje seçim sürecinde, Sarı (2017) ArGe projelerinin önceliklerinin belirlenmesi sürecinde, Moghimi ve Yazdi (2016) bölgelerin ekonomik performansını değerlendirme sürecinde, Vujicic vd. (2017) klima seçim sürecinde, Bhowmik vd. (2018) yeşil enerji kaynağı seçim sürecinde kriterlerin ağırlıklandırılmasında Entropi yöntemini uygulamışlardır. GIA ve MOORA yöntemleri ise problemde yer alan alternatiflerin belirli kriterler dikkate alınarak sıralanmasını ve en iyi alternatiflerin 
bulunmasını sağlamaktadır. Tsai vd. (2003) tedarikçi değerlendirmede, Peker ve Baki (2011) performans ölçümünde, Hasani vd. (2012) optimum süreç parametrelerini belirlemede, Şişman ve Eleren (2013) otomobil seçiminde, Kundakçı (2016) personel seçiminde, Hsiao (2017) ürün geliştirmede, Kabak ve Dağdeviren (2017) makine seçiminde GiA yöntemini kullanmışlardır. Brauers vd. (2010) bölgelerin performans değerlendirmesinde, Gadakh (2011) optimum parametre seçiminde, Sarkar vd. (2015) makine seçiminde, Şimşek vd. (2015) tedarikçi seçiminde, Adalı ve Tuş (2017) bilgisayar seçiminde, Brauers vd. (2008), Dwivedi ve Pwivedi (2018) tedarikçi seçiminde MOORA yöntemini uygulamışlardır.

\section{Entropi}

Entropi kavramı 1865 yılında Clausius tarafından, termodinamikte düzensizlik ve dağınıklığın bir ölçütü olarak literatüre giren bir kavramdır. Bu kavram Shannon (1948) tarafından kesikli olasılık dağılımı ile açıklanan belirsizliğin ölçüsü olarak farklı bir şekilde enformasyon teorisi açısından tanımlanmıştır (Zhang vd., 2011: 444).

Birden çok kriteri içerisinde bulunduran karar verme problemlerinde, kriter ağılıklarının hesaplanması oldukça önemli bir konudur. Entropi yöntemi literatürde yer alan ağırlık hesaplama yöntemlerinden objektif olanlar kategorisinde değerlendirilmektedir. Entropi yönteminde karar probleminde yer alan kriterlere ilişkin ağırlıklarının hesaplanması için, karar matrisindeki veriler kullanılmaktadır. Başka herhangi bir subjektif değerlendirmeye ihtiyaç duyulmaması nedeniyle yöntemin uygulanabilirliği oldukça kolaydır. Entropi yöntemi beş aşamadan oluşan bir uygulama sürecine sahiptir (Erol ve Ferrell, 2009: 1196-1197; Wang ve Lee, 2009: 8982; Özdağoğlu vd..2017: 346-347; Vujičić vd., 2017: 425).

1. Aşama: Karar Matrisinin Oluşturulması: Yöntemin ilk aşamasında $x_{i j}$ değerlerinden oluşan ve $D$ ile simgelenen karar matrisi Eşitlik (1)'de gösterilen şekilde oluşturulur.

$$
\left.D=\underset{A_{2}}{A_{1}} \begin{array}{cccc}
x_{11} & x_{12} & \ldots & x_{1 n} \\
x_{m} & x_{22} & \ldots & x_{2 n} \\
\vdots & \vdots & \ldots & \vdots \\
x_{m 1} & x_{m 2} & \ldots & x_{m n}
\end{array}\right]
$$

Eşitlik (1)'de yer alan $x_{i j}$ değerleri, $j$. değerlendirme kriterine göre i. alternatifin aldığı değerleri göstermektedir ( $i$, karar alternatifi sayısı $i=1,2, \ldots, m ; j$ ise değerlendirme kriteri sayısı $j=1,2, \ldots, n$ sayısı).

2. Aşama: Karar Matrisinin Normalizasyonu: Karar problemlerinde yer alan farklı birimlere sahip kriterlere ait veriler, normalizasyon işlemiyle [0,1] aralığında değer alacak şekilde standart bir hale getirilmelidir. Normalizasyon işlemi Eşitlik (2)'den yararlanılarak gerçekleştirilir.

$$
p_{i j}=\frac{x_{i j}}{\sum_{i=1}^{m} x_{i j}} \forall i, j
$$

Eşitlik (2)'de yer alan $p_{i j}$ : değerleri, $j$. değerlendirme kriterine göre $i$. alternatifin aldığı normalize değeri göstermektedir.

3. Aşama: Entropi Değerlerinin Bulunması: Bu aşamada her bir değerlendirme kriterinin belirsizlik ölçüsü olan Entropi değerleri $\left(e_{j}\right)$, Eşitlik (3)'te gösterilen şekilde hesaplanır.

$$
e_{i j}=-k \cdot \sum_{j=1}^{n} p_{i j} \cdot \ln \left(p_{i j}\right) \quad i=1,2, \ldots, m \text { ve } j=1,2, \ldots, n
$$


Eşitlik (3)'de yer alan $k$ değeri $k=(\ln (m))^{-1}$ olarak tanımlanan sabit bir katsayıdır ve $0 \leq$ $e_{j} \leq 1$ olacak şekilde değer alır.

4. Aşama: Farklılaşma Derecelerinin Bulunması: Bu aşamada, bir önceki aşamada hesaplanan Entropi değerleri kullanılarak, farklılaşma dereceleri olan $d_{j}$ değerleri her bir kriter için Eşitlik (4)'te gösterilen şekilde hesaplanır.

$$
d_{j}=1-e_{j} \quad j=1,2, \ldots, n
$$

5. Aşama: Entropi Kriter Ağırıklarının Hesaplanması: Yöntemin son aşamasında her bir kriterin farklılaşma derecesini, toplam farklılaştırma derecesine oranlayarak kriterlerin ağırlık değerleri $\left(\mathrm{w}_{\mathrm{j}}\right.$ ) Eşitlik (5)'te gösterilen şekilde hesaplanır.

$$
w_{j}=\frac{d_{j}}{\sum_{j=1}^{n} d_{j}}
$$

Entropi yönteminde kriterlere ilişkin Entropi değerleri hesaplanırken, doğal logaritma fonksiyonu kullanılmaktadır. Karar problemine ilişkin verilerde sıfır ya da negatif değerlerinin olması durumunda, logaritmik hesaplamalar yapılamadığından, bu veriler için düzeltmeler yapılmalıdır. Bu çalışmada Zhang vd. (2014) tarafından geliştirilen Z-skoru standartlaştırma dönüşümü kullanılan entropi (improved entropy) yöntemi ile sıfır ve negatif sayılar için düzeltmeler yapılmıştır. Bu yöntemde önce karar matrisinde yer alan değerler Eşitlik (6)'dan yararlanılarak Z-skoru standartlaştırması ile dönüştürülür.

$$
z_{i j}=\frac{x_{i j}-\bar{X}_{j}}{\sigma_{j}}
$$

Daha sonra Eşitlik (7)'de gösterilen dönüşüm yapılarak karar matrisindeki veriler pozitif hale getirilmiş olur.

$$
z_{i j}^{\prime}=z_{i j}+A ; \quad A>\left|\min z_{i j}\right|
$$

\section{Gri iliş̧kisel Analiz}

Gri İlişkisel Analiz (GIA), Denk tarafından literatüre kazandırılan Gri sistem teorisi (Denk,1989) temelinde geliştirilmiş olan önemli bir sınıflama, derecelendirme ve karar verme yöntemidir. GIA, nicel ve nitel verileri içinde bulunduran ÇKKV problemlerinin çözümünde hem tek başına hem de diğer yöntemlerle bütünleşik bir şekilde kullanılabilir.

Az sayıda veriye ihtiyaç duyması, belirsizlik durumunda verilerle etkin sonuçlar üretebilmesi, gri ilişki katsayılarının hesaplanmasının kolay olması ve veri setinin herhangi bir dağılıma uygun olma zorunluluğunun olmaması yöntemin avantajlı yönleridir. Bir olasılık dağılımından bağımsız olan GíA, küçük örnek hacimleri ile yapılan çalışmalarda diğer istatistiksel analiz tekniklerine göre daha iyi sonuçlar ortaya koyabilmektedir (Kung vd., 2006:156). Gri İlişkisel Analiz yönteminin uygulama süreci altı aşamadan oluşmaktadır (Hsu ve Wen, 2000; Wu, 2002; Lin ve Lin, 2005; Zhai vd., 2009; Yıldırım ve Önder, 2015; Özbek ve Demirkol, 2018):

1. Aşama: Verilerin Hazırlanması ve Karar Matrisinin Oluşturulması: Yöntemin ilk aşamasında karar probleminde yer alan, karşılaştırma yapılacak $m$ adet faktör serisi Eşitlik (8)'de gösterilen şekilde belirlenir.

$$
x_{i}=\left(x_{i}(j), \ldots,{ }_{i} x_{i}(n)\right) \mathrm{i}=1,2, \ldots, \mathrm{m} ; \mathrm{j}=1,2, \ldots, \mathrm{n}
$$


Eşitlik (8)'de yer alan $x_{i}{ }^{\prime}$ 'ler karar alternatiflerini; $x_{i}(j)$ değerleri ise $i$. karar alternatifinin j. kriter için aldığı değeri göstermektedir. $m$ adet serinin oluşturulmasıyla elde edilen karar matrisi " $X$ ”, Eşitlik (9)'da gösterilmiştir.

$$
X=\left[\begin{array}{cccc}
x_{1}(1) & x_{1}(2) & \cdots & x_{1}(n) \\
x_{2}(1) & x_{2}(2) & \cdots & x_{2}(n) \\
\vdots & \vdots & \cdots & \vdots \\
\vdots & \vdots & \cdots & \vdots \\
\vdots & \vdots & \ddots & \vdots \\
x_{m}(1) & x_{m}(2) & \cdots & x_{m}(n)
\end{array}\right]
$$

2. Aşama: Referans Serisinin ve Karşılaştırma Matrisinin Oluşturulması: Bu aşamada öncelikle, karar probleminde yer alan faktörleri kıyaslamak amacıyla Eşitlik (10)'de gösterilen şekilde referans seri oluşturulur.

$$
x_{0}=\left(x_{0}(j)\right) \mathrm{j}=1,2, \ldots, \mathrm{n}
$$

Eşitlik (10)'da yer alan $x_{0}(j)$ değeri, $j$. kriterin bir sonraki aşamada elde edilecek normalize değerler arasındaki, en iyi değerini göstermektedir. Referans seri, bir karar alternatifi için kriterler göz önüne alındığında, her bir kriter için ideal değerleri belirlenerek oluşturulabilir. Referans serinin belirlenmesindeki diğer yol ise, karar alternatiflerinin her bir kriter için aldıkları değerlerin en iyilerini kullanmaktır. Fayda yönlü kriterlerde, o kriter için veri setinde yer alan en büyük değerin referans seriye alınması gerekirken; maliyet yönlü kriterlerde ise en küçük değer referans seriye alınarak, referans seri oluşturulur. Referans seri oluşturulduktan sonra, ilk aşamada oluşturulan karar matrisinin ilk satırına eklenerek, karşılaştırma matrisi elde edilir.

3. Aşama: Normalizasyon İşlemi ve Normalize Matrisinin Elde Edilmesi: Normalizasyon işlemi fayda, maliyet ve optimal (en uygun) durumlarına göre üç farklı şekilde gerçekleştirilebilir. Fayda durumundaki kriterler dikkate alındığında, kriterin alacağı değerin en büyük olması amaca uygun olmaktadır. Fayda durumuna ilişkin normalizasyon işlemi Eşitlik (11) kullanılarak gerçekleştirilir.

$$
x_{i}^{*}=\frac{x_{i}(j)-\min _{j} x_{i}(j)}{\max _{j} x_{i}(j)-\min _{j} x_{i}(j)}
$$

Maliyet durumundaki kriterler dikkate alındığında, kriterin alacağı değerin en küçük olması amaca uygun olmaktadır. Maliyet durumuna ilişkin normalizasyon işlemi Eşitlik (12) kullanılarak gerçekleştirilir.

$$
x_{i}^{*}=\frac{\max _{j} x_{i}(j)-x_{i}(j)}{\max _{j} x_{i}(j)-\min _{j} x_{i}(j)}
$$

Optimal durumun dikkate alınması gereken kriterler mevcutsa, kriterin bu optimal değeri alması amaca uygun olmaktadır. Optimal duruma ilişkin normalizasyon işlemi Eşitlik (13) kullanılarak gerçekleştirilir.

$$
x_{i}^{*}=\frac{x_{i}(j)-x_{0 b}(j)}{\max _{j} x_{i}(j)-x_{0 b}(j)}
$$


Eşitlik (13)'de yer alan $x_{0 b}(j)$ değeri, belirlenen optimal değer olup $j$. kriterin hedef değerini göstermektedir. Optimal değer $\min _{j} x_{i}(j) \leq x_{0 b} \leq \max _{j} x_{i}(j)$ aralığında değer alabilir. Normalize edilmiş karar matrisi ise Eşitlik (14)'de gösterilmiştir.

$$
X^{*}=\left[\begin{array}{cccc}
x_{1}{ }^{*}(1) & x_{1}{ }^{*}(2) & \cdots & x_{1}{ }^{*}(n) \\
x_{2}{ }^{*}(1) & x_{2}{ }^{*}(2) & \cdots & x_{2}{ }^{*}(n) \\
\vdots & \vdots & \cdots & \vdots \\
\vdots & \vdots & \cdots & \vdots \\
\vdots & \vdots & \ddots & \vdots \\
x_{m}{ }^{*}(1) & x_{m}{ }^{*}(2) & \cdots & x_{m}{ }^{*}(n)
\end{array}\right]
$$

4. Aşama: Fark Matrisinin Oluşturulması: Bu aşamada referans serinin normalize değerleri ile normalize karar matrisinin değerleri arasındaki farkın değeri Eşitlik (15)'de gösterilen şekilde hesaplanır.

$$
\Delta_{0 i}=x_{0}^{*}(j)-x_{i}^{*}(j)
$$

Eşitlik (15)'den yararlanılarak hesaplanan değerler ile Eşitlik (16)'da gösterilen fark matrisi elde edilir.

$$
\Delta_{0 i}=\left[\begin{array}{cccc}
\Delta_{01}(1) & \Delta_{01}(2) & \cdots & \Delta_{01}(n) \\
\Delta_{02}(1) & \Delta_{02}(2) & \cdots & \Delta_{02}(n) \\
\vdots & \vdots & \cdots & \vdots \\
\vdots & \vdots & \cdots & \vdots \\
\vdots & \vdots & \ddots & \vdots \\
\Delta_{0 m}(1) & \Delta_{0 m}(2) & \cdots & \Delta_{0 m}(n)
\end{array}\right]
$$

5. Aşama: Gri ilişskisel Katsayı Matrisinin Oluşturulması: Gri ilişkisel katsayı matrisinde yer alan elemanlar Eşitlik (17), (18) ve (19) kullanılarak hesaplanmaktadır.

$$
\begin{aligned}
\gamma_{0 i}(j) & =\frac{\Delta_{\min }+\zeta \cdot \Delta_{\max }}{\Delta_{0 i}(j)+\zeta \cdot \Delta_{\max }} \\
\Delta_{\max } & =\max _{i} \max _{j} \Delta_{0 i}(j) \\
\Delta_{\min } & =\min _{i} \min _{j} \Delta_{0 i}(j)
\end{aligned}
$$

Eşitlik (17)'de yer alan ve [0,1] aralığında değer alabilen " $\zeta$ "parametresi, "ayırıcı katsayı" veya "zıtık kontrol katsayısı" olarak adlandırılır. Bu katsayı $\Delta_{0 i}$ ile $\Delta_{\max }$ arasındaki farkı düzenlemek için kullanılmaktadır. " $\zeta$ “parametresinin aldığı değer 1'e doğru yaklaştıkça ayırıcı özellik (zıtlık) artacaktır. Bu değer 0’a doğru yaklaştıkça ise zıtlığın ortadan kalkacağı bir durum ortaya çıkacaktır. Veri setinde yer alan değerler arasındaki farkların çok fazla olması durumunda, zıtlığı azaltmak amacıyla " $\zeta$ "parametresi olarak sıfıra yakın değerler seçilir. Literatürdeki çalışmalar incelendiğinde, birçoğunda bu katsayının 0,5 olarak kullanıldığı görülmüştür.

6. Aşama: Gri ilişkisel Derecelerin Belirlenmesi: Gri ilişkisel derece, gri bir sistemde yer alan $x_{i}{ }^{*}$ serisi ile referans seri $\left(x_{0}{ }^{*}\right)$ arasındaki geometrik benzerliğin bir ölçüsüdür. Gri ilişkisel dereceler $\left(\Gamma_{0 i}\right)$, karar probleminde yer alan kriterlerin önem düzeylerine göre farklı şekillerde 
hesaplanır. Eğer karar problemindeki kriterler eşit önem düzeyinde değerlendiriliyorsa, gri ilişkisel derece Eşitlik (20), farklı önem düzeyinde değerlendiriliyorsa Eşitlik (21) yardımıyla hesaplanır.

$$
\begin{gathered}
\Gamma_{0 i}=\frac{1}{n} \sum_{j=1}^{n} \gamma_{0 i}(j) \\
\Gamma_{0 i}=\sum_{j=1}^{n}\left[w_{i}(j) \cdot \gamma_{0 i}(j)\right]
\end{gathered}
$$

Eşitlik (21)'da yer alan $w_{i}(j)$ değeri $j$. kriterin, kriter ağırlığını göstermektedir. Kriterlere ilişkin ağırlık değerleri toplamı 1 olmalıdır. Gri ilişkisel derecelerin hesaplanması ile yöntemin son aşaması tamamlanmış olur. Gri ilişkisel dereceler, büyükten küçüğe doğru sıralanarak karar alternatiflerine ilişkin sıralama elde edilir. En yüksek gri ilişkisel derece değerine sahip karar alternatifi, en iyi alternatif olarak belirlenir.

\section{MOORA}

Oransal analize dayalı çok amaçlı optimizasyon yöntemi olan MOORA, içerisinde çok sayıda değerlendirme kriterini bulunduran karar verme problemlerinde kullanılan bir yöntemdir (Brauers ve Zavadskas, 2006). MOORA Yöntemine yönelik uygulamalar genellikle MOORAOran ve MOORA-Referans Noktası yaklaşımlarından oluşmaktadır. Ayrıca karar problemlerini değerlendirirken dikkate alınan kriterlerin eşit ağırlıklı önem sahip olduğu varsayılmadığı durumlarda MOORA-Önem Katsayısı yaklaşımı kullanılmaktadır. Birçok ÇKKV yönteminde olduğu gibi MOORA yönteminin de ilk aşaması karar matrisinin oluşturulmasıdır. Karar alternatiflerin kriterlere göre aldıkları değerleri gösteren karar matrisi Eşitlik (22)'de gösterildiği gibidir.

$$
X=\left[\begin{array}{cccc}
x_{11} & x_{12} & \ldots & x_{1 n} \\
x_{21} & x_{22} & \ldots & x_{2 n} \\
\vdots & \vdots & \ldots & \vdots \\
x_{j 1} & x_{j 2} & \ldots & x_{j n} \\
\vdots & \vdots & \ldots & \vdots \\
x_{m 1} & x_{m 2} & \ldots & x_{m n}
\end{array}\right] \quad i=0,1, \ldots, m ; \quad j=1,2, \ldots, n
$$

Eşitlik (22)'de yer alan ;

$\checkmark$ “ $m$ ", karar alternatif sayısını

$\checkmark$ " $n$ ", değerlendirme kriter sayısını

$\checkmark$ “ $x_{i j}$ ", j. kritere göre i. karar alternatifinin aldığı değeri göstermektedir.

Karar matrisi oluşturulduktan sonra MOORA yaklaşımları ile uygulamaya devam edilmelidir. MOORA yaklaşımları ve uygulama aşamaları aşağıda anlatılan adımları içermektedir (Brauers ve Zavadskas, 2006: 447-448; Brauers vd., 2008: 248-249; Brauers ve Ginevicius, 2009: 123-124; Brauers, 2013: 42-44; Vujičić vd., 2017: 423).

\subsection{MOORA-Oran Yaklaşımı}

MOORA-Oran yaklaşımının ilk adımında Eşitlik (22)'de gösterilen karar matrisi normalize edilir. Her bir karar alternatifinin kriterlere göre aldıkları değerler, Eşitlik (23)'den yararlanılarak normalizasyon işlemi tamamlanır. 


$$
x_{i j}^{*}=\frac{x_{i j}}{\sqrt{\sum_{i=1}^{m} x_{i j}^{2}}}
$$

Eşitlik (23)'de yer alan $x_{i j}{ }^{*}$ değeri, j. kritere göre i. karar alternatifinin aldığı değerin normalize edilmiş değeridir. Normalize edilen değerler hesaplandıktan sonra, karar probleminde yer alan kriterler maksimizasyon ya da minimizasyon yönlü olacak şekilde belirlenir. Her bir karar alternatifi için, maksimizasyon yönlü kriterlerin aldığı değerler toplamından, minimizasyon yönlü kriterlerin aldığı değerler toplamı çıkarılır ve $y_{i}{ }^{*}$ değerleri elde edilir.

$j=1,2, \ldots, g$ maksimum yönlü kriterler, $j=g+1, g+2, \ldots, n$ minimizasyon yönlü kriterler olacak şekilde $y_{i}{ }^{*}$ değerleri, Eşitlik (24) yardımıyla hesaplanır.

$$
y_{i}^{*}=\sum_{j=1}^{g} x_{i j}{ }^{*}-\sum_{j=g+1}^{n} x_{i j}{ }^{*}
$$

Eşitlik (24)'de yer alan $y_{i}{ }^{*}$ değeri, i. karar alternatifinin tüm kriterlere göre normalleştirilmiş değerini ifade etmektedir. $y_{i}{ }^{*}$ değerleri büyükten küçüğe doğru olacak şekilde, MOORA-Oran yaklaşımına göre karar alternatifleri sıralanabilir, en uygun alternatif belirlenebilir.

\subsection{MOORA-Önem Katsayısı Yaklaşımı}

MOORA-Oran yaklaşımında kriterlerin eşit derecede önem düzeyine sahip oldukları kabul edilmektedir. Ancak uygulamalarda bu durum her zaman gerçekleşmeyebilir. Bazı durumlarda, kriterlerin birbirlerine göre farklı önem düzeyine sahip oldukları görülmektedir. Dolayısıyla MOORA-Oran yaklaşımında elde edilen normalize değerler, her kriter kendi önem düzeyini yansıtacak şekilde belirlenen önem katsayıları $\left(w_{j}\right)$ ile çarpılır. Karar alternatiflerinin tüm kriterlere göre normalleştirilmiş değerlendirmesini gösterecek olan $\hat{y}_{i}^{*}$ değerleri Eşitlik (25) yardımıyla hesaplanır.

$$
\hat{y}_{i}^{*}=\sum_{j=1}^{g} w_{j} x_{i j}{ }^{*}-\sum_{j=g+1}^{n} w_{j} x_{i j}{ }^{*}
$$

Eşitlik (25)'de hesaplanan $\hat{y}_{i}^{*}$ değerleri büyükten küçüğe doğru olacak şekilde, MOORAÖnem Katsayısı yaklaşımına göre karar alternatifleri sıralanabilir, en uygun karar alternatifi belirlenebilir.

\subsection{MOORA-Referans Noktası Yaklaşımı}

MOORA-Referans Noktası yaklaşımının ilk adımında, MOORA-Oran yaklaşımı ile Eşitlik (28)'de gösterilmiş olan normalize edilmiş değerler dikkate alınır. Bu yaklaşımda MOORA-Oran yaklaşımından farklı olarak, karar alternatiflerinin her bir kritere göre, maksimizasyon yönlü kriterler için en büyük değeri, minimizasyon yönlü kriterler için en küçük değeri dikkate alınarak referans noktaları $\left(r_{j}\right)$ belirlenir. $\left(d_{i j}\right)$ değerleri ise Eşitlik (26) yardımıyla belirlenir.

$$
d_{i j}=\left|r_{j}-x_{i j}^{*}\right|
$$


Eşitlik (26)'da yer alan:

$\checkmark d_{i j}$ değeri, referans noktalara olan uzaklığı

$\checkmark \quad r_{j}$ değeri, j. kriterin referans noktasını

$\checkmark \quad x_{i j}{ }^{*}$ değeri, j. kritere göre i. karar alternatifinin aldığı değerin normalize edilmiş değerini göstermektedir.

i. karar alternatifinin, değerlendirme yapılan maksimizasyon ve minimizasyon yönlü tüm kriterler için toplam sapmasını gösterecek olan (Pi) değeri, Eşitlik (27) yardımıyla hesaplanır. $(P i)$ değerleri küçükten büyüğe doğru olacak şekilde, MOORA-Referans Nokta yaklaşımına göre karar alternatifleri sıralanabilir, en uygun alternatif belirlenebilir.

$$
\min _{i}=\left\{\max _{j}\left(\left|r_{j}-x_{i j}^{*}\right|\right)\right\}
$$

Eşitlik 27'de hesaplanan $(P i)$ değerleri, kriterlerin eşit derecede önem düzeyine sahip oldukları durumlar için hesaplanmıştır. Karar probleminde yer alan kriterlerin farklı önem düzeylerine sahip oldukları durumlarda ise Eşitlik (28)'den yararlanılarak (Pi) değerleri hesaplanmalıdır.

$$
\min _{i}=\left\{\max _{j}\left(\left|w_{j} \cdot r_{j}-w_{j} \cdot x_{i j}^{*}\right|\right)\right\}
$$

\section{Uygulama}

$B u$ çalışmada $A B$ ve $A B^{\prime}$ ye aday ülkelerin çevresel performansının Entropi, GiA ve MOORA ÇKKV teknikleri ile bütünleşik olarak ölçülmesi amaçlanmıştır. Çalışma kapsamında gerekli olan verilere Yale ve Columbia Üniversitelerinin ortak hazırladığı iki yılda bir hazırladığı ve 24 çevresel performans gösterge kullanarak 180 ülkenin çevresel performansının ölçüldüğü raporlardan ulaşılmıştır. Çevresel performans indeksi kapsamında dikkate alınan değişkenler ve değişkenlerin ağırlıkları Tablo 1'de yer almaktadır.

\begin{tabular}{|c|c|c|}
\hline Ana Değişkenler & 1. Alt Değişkenler & 2. Alt Değişkenler \\
\hline \multirow{3}{*}{$\begin{array}{l}\text { Çevresel Sağlık } \\
\quad(0,40)\end{array}$} & Hava Kalitesi-C1 $(0,65)$ & $\begin{array}{l}\mathrm{PM}_{25} \text { fazlalığı }(0,30), \mathrm{PM}_{25} \text { maruziyeti }(0,30) \text {, Hanehalkı katı yakıtlar } \\
(0,40)\end{array}$ \\
\hline & Su Kalitesi-C2 $(0,30)$ & Sanitasyon $(0,50)$, İçilebilir Su $(0,50)$ \\
\hline & Ağır Metaller-C3 $(0,05)$ & Kurşun maruziyeti $(1,00)$ \\
\hline \multirow{7}{*}{$\begin{array}{l}\text { Ekosistem } \\
\text { Canlılığı } \\
(0,60)\end{array}$} & $\begin{array}{l}\text { Biyoçeşitlilik ve Doğal } \\
\text { Ortam-C4 }(0,25)\end{array}$ & $\begin{array}{l}\text { Deniz koruma alanları }(0,20) \text {, Küresel biom koruma }(0,20) \text {, Ulusal biom } \\
\text { koruma }(0,20) \text {, Tür koruma indeksi }(0,20) \text {, Tür indeksi }(0,10) \text {, Tür doğal } \\
\text { ortam indeksi }(0,10)\end{array}$ \\
\hline & Ormanlar-C5 $(0,10)$ & Ağaç örtüsü kaybı $(1,00)$ \\
\hline & Balıkçılık-C6 $(0,10)$ & Balık stok durumu $(0,50)$, Bölgesel deniz endeksi $(0,50)$ \\
\hline & $\begin{array}{l}\text { İklim ve Enerji-C7 } \\
\qquad(0,30)\end{array}$ & $\begin{array}{l}\text { Karbondioksit emisyonu-toplam }(0,50) \text {, Karbondioksit emisyonu-güç } \\
(0,20) \text {, Metan emisyonu }(0,20) \text {, Azotprotoksit emisyonu }(0,05) \text {, Siyah } \\
\text { karbon emisyonu }(0,05)\end{array}$ \\
\hline & Hava Kirliliği-C8 $(0,10)$ & Kükürtdioksit emisyonu $(0,50)$, Azotoksit emisyonu $(0,50)$ \\
\hline & $\begin{array}{c}\text { Su Kaynakları-C9 } \\
(0,10)\end{array}$ & Atık su arıtma $(1,00)$ \\
\hline & Tarım-C10 $(0,05)$ & Sürdürülebilir nitrojen yönetimi $(1,00)$ \\
\hline
\end{tabular}

Tablo 1: Çevresel Performans Indeksi Kapsamında Dikkate Alınan Değişkenler

Kaynak: Environmental Performance Index, 2018: 3 
Çevresel performans indeksi kapsamında 2. alt değişkenlere ait veriler parantez içindeki ağılıkları ile çarpılıp toplanarak 1. alt değişkenlere ait veriler bulunmaktadır. Daha sonra hesaplanan 1. alt değişkenlere ait veriler ve ağılıkları çarpılıp toplanarak ana değişkenlere ait veriler, ana değişkenlere ait veriler de ağırlıkları ile çarpılıp toplanarak her ülkenin çevresel performans indeksi hesaplanmaktadır. Bu çalışma kapsamında sadece 1. alt değişkenler ve sadece $A B$ ve $A B^{\prime}$ ye aday ülkeler ele alınarak çevresel performans ölçümü yapılmış olup, probleme ait karar matrisi aşağıda Tablo 2'de yer almaktadır.

Tablo 2: Çalışma Kapsamında Oluşturulan Karar Matrisi

\begin{tabular}{|c|c|c|c|c|c|c|c|c|c|c|}
\hline ÜLKELER & C1 & C2 & C3 & C4 & C5 & C6 & $\mathrm{C7}$ & $\mathrm{C8}$ & C9 & C10 \\
\hline AVUSTURYA & 82,21 & 94,63 & 91,08 & 91,69 & 27,6 & 74,3 & 62,79 & 86,31 & 99,08 & 71,34 \\
\hline BELÇiKA & 88,63 & 96,09 & 58,6 & 95,7 & 15,61 & 46,69 & 63,81 & 79,02 & 98,08 & 47,61 \\
\hline BULGARISTAN & 68,49 & 71,26 & 74,15 & 93,39 & 34,38 & 62,17 & 56,04 & 52,91 & 93,93 & 43,68 \\
\hline HIRVATISTAN & 64,07 & 70,01 & 87,84 & 95,25 & 34,36 & 54,55 & 54,41 & 43,23 & 86,58 & 47,68 \\
\hline KIBRIS & 87,5 & 92,35 & 67,57 & 81,66 & 36,06 & 52,55 & 66,26 & 49,65 & 79,34 & 6,29 \\
\hline ÇEK CUMHURIYETI & 65,77 & 69,98 & 98,82 & 94,96 & 17,8 & 67,21 & 54,65 & 57,07 & 95,77 & 62,17 \\
\hline DANIMARKA & 99,16 & 97,78 & 88,3 & 94,48 & 12,74 & 50,75 & 67,56 & 71 & 98,45 & 67,02 \\
\hline ESTONYA & 78,87 & 58,45 & 88,82 & 92,39 & 4,56 & 76,04 & 33,62 & 54,29 & 96,42 & 40,75 \\
\hline FINLANDIYA & 99 & 100 & 100 & 89,25 & 5,98 & 61,11 & 62,33 & 49,1 & 97,01 & 49,97 \\
\hline FRANSA & 95,97 & 97,22 & 83,29 & 96,25 & 25,08 & 57,71 & 70,46 & 96,82 & 95,56 & 67,77 \\
\hline ALMANYA & 84,09 & 96,74 & 100 & 96,92 & 34,99 & 47,71 & 55,47 & 93,3 & 99,65 & 61,21 \\
\hline YUNANISTAN & 89,23 & 100 & 60,77 & 90,89 & 33,42 & 63,74 & 42,17 & 46,41 & 97,72 & 49,5 \\
\hline MACARISTAN & 52,3 & 66,26 & 75,88 & 91,7 & 11,64 & 70,02 & 61,68 & 75,22 & 93,42 & 69,15 \\
\hline İRLANDA & 95,78 & 100 & 73,18 & 88,63 & 8,78 & 71,14 & 54,16 & 87,23 & 91,19 & 61,94 \\
\hline ITALYA & 80,56 & 100 & 70,23 & 94,1 & 30,96 & 37,99 & 65,14 & 88,55 & 97,53 & 49,03 \\
\hline LETONYA & 77,66 & 60,62 & 82,78 & 92,05 & 3,67 & 50,65 & 42,89 & 84,31 & 96,3 & 45,68 \\
\hline LITVANYA & 77,97 & 58,51 & 86,63 & 93,83 & 7,75 & 57,83 & 62,46 & 59,73 & 93,49 & 62,01 \\
\hline LÜKSEMBURG & 93,62 & 99,3 & 88,55 & 96,54 & 18,77 & 68,77 & 58,53 & 61,82 & 99,76 & 38,06 \\
\hline MALTA & 94,4 & 100 & 48,74 & 87,77 & 72,49 & 56,49 & 67,04 & 57,32 & 100 & 32,62 \\
\hline HOLLANDA & 89,68 & 98,26 & 89,8 & 80,13 & 35,79 & 34,6 & 52,55 & 96,56 & 99,9 & 35,39 \\
\hline POLONYA & 69,23 & 53,04 & 69,29 & 96,37 & 14,26 & 42,66 & 64,33 & 72,3 & 92,35 & 43,37 \\
\hline PORTEKIZ & 90,99 & 93,59 & 64,91 & 91,41 & 0 & 32,11 & 56,89 & 67,18 & 93,82 & 6,09 \\
\hline ROMANYA & 59,9 & 57,37 & 68,25 & 90,8 & 27,82 & 48,86 & 68,53 & 71,2 & 83,95 & 48,15 \\
\hline SLOVAKYA & 59,42 & 69,62 & 87,21 & 94,31 & 17,09 & 75,33 & 74,21 & 79,51 & 89,95 & 61,53 \\
\hline SLOVENYA & 71,25 & 70,59 & 97 & 95,78 & 30,87 & 64,67 & 51,16 & 49,85 & 88,5 & 34,85 \\
\hline ISPANYA & 100 & 94,07 & 61,27 & 95,66 & 8,95 & 43,14 & 67,77 & 69,34 & 99,71 & 29,74 \\
\hline ISVEÇ & 92,84 & 96,88 & 100 & 81 & 5,53 & 53,76 & 86,8 & 64,17 & 98,49 & 55,12 \\
\hline BİRLEŞİK KRALLIK & 94,43 & 100 & 93,09 & 96,69 & 6,9 & 42,16 & 63,06 & 82,87 & 99,82 & 57,34 \\
\hline TÜRKIYE & 78,2 & 59,28 & 58,96 & 25,16 & 27,39 & 38,64 & 39,99 & 44,41 & 92,21 & 40,25 \\
\hline MAKEDONYA & 66,43 & 69,16 & 70,11 & 64,85 & 30,62 & 57,1 & 63,85 & 56,99 & 52,07 & 35,99 \\
\hline ARNAVUTLUK & 65,47 & 66,56 & 62,89 & 75,37 & 23,36 & 58,25 & 68,36 & 86,07 & 80,73 & 22,61 \\
\hline SIRBISTAN & 56,67 & 69,73 & 68,53 & 49,84 & 38,66 & 55,22 & 61,77 & 59,76 & 60,49 & 52,95 \\
\hline BOSNA HERSEK & 60,37 & 71,54 & 63,39 & 26,93 & 49,31 & 27,25 & 26,8 & 30,79 & 0 & 33,09 \\
\hline KARADAĞ & 69,28 & 78,61 & 79,89 & 73,77 & 30,77 & 36,18 & 46,85 & 59,22 & 81,67 & 10,57 \\
\hline
\end{tabular}


Değişkenler arasında minimum olması gereken bir değişken verilerin hesaplanması sürecinde en yüksek değer en düşük değere, en düşük değerde en yüksek değere dönüştürülerek dönüşüm yapıldığından karar matrisinde yer alan tüm değerler maksimizasyon yönlüdür.

Çevresel Performans İndeksi 2018 verileri incelediğinde; hava kalitesi değişkeni bakımından performansı en iyi ülkelerin İspanya $(100)$, Danimarka $(99,16)$, Finlandiya $(99)$ ve performansı en kötü olan ülkelerin ise Slovakya $(59,42)$, Sırbistan $(56,67)$ ve Macaristan $(52,3)$ olduğu görülmektedir. Su kalitesi değişkeni açısından değerlendirildiğinde en iyi ülkelerin Finlandiya (100), Yunanistan (100), İrlanda (100) ve en zayıf ülkelerin Estonya $(58,45)$, Romanya $(57,37)$, Polonya $(53,04)$ olduğu incelenmiştir. Ağır metaller bakımından performansı en iyi ülkeler Finlandiya (100), Almanya (100) ve İsveç (100), performansı en kötü olan ülkeler ise Türkiye $(58,96)$, Belçika $(58,6)$ ve Malta $(48,74)^{\prime}$ dır. Biyoçeşitliliği en fazla olan ülkeler Almanya $(96,92)$, Ingiltere $(96,69)$ ve Lüksemburg $(96,54)$ en az olan ülkeler ise Sırbistan $(49,84)$, Bosna Hersek $(26,93)$ ve Türkiye $(25,16)$ 'dir. Ormanlar değişkeni açısından Malta $(72,49)$, Bosna Hersek $(49,31)$, Sırbistan $(38,66)$ en iyi ülkeler, Estonya $(4,56)$, Letonya $(3,67)$ ve Portekiz (0) en zayıf ülkelerdir. Balıkçılık konusunda en güçlü ülkeler Estonya $(76,04)$, Slovakya $(75,33)$ ve Avusturya $(74,30)$, en zayıf ülkeler ise Hollanda $(34,6)$, Portekiz $(32,11)$ ve Bosna Hersek $(27,25)^{\prime}$ tir. İsveç $(86,8)$, Slovakya $(74,21)$ ve Fransa $(70,46)$ iklim ve enerji açısından en iyi ülkeler, Türkiye $(39,99)$, Estonya $(33,62)$ ve Bosna Hersek $(26,8)$ en kötü ülkelerdir. Hava kirliliğinin en fazla olduğu ülkeler Türkiye $(44,41)$, Hırvatistan $(43,23)$ ve Bosna Hersek $(30,79)$, en az olduğu ülkeler ise Fransa $(96,82)$, Hollanda $(96,52)$ ve Almanya $(93,3)$ 'dır. Su kaynakları bakımından incelendiğinde, Malta $(100)$, Hollanda $(99,9)$ ve İngiltere $(99,82)$ performansı en iyi ülkeler, performansı en kötü ülkeler ise Sırbistan $(60,49)$, Makedonya $(52,07)$ ve Bosna Hersek (0)'tir. Son olarak tarım değişkeni ele alındığında, Avusturya (71,34), Macaristan $(69,15)$ ve Fransa $(67,77)$ 'nın en güçlü ülkeler olduğu, en zayıf ülkelerin ise Karadağ $(10,57)$, Kıbrıs $(6,29)$ ve Portekiz $(6,09)$ olduğu görülmektedir. Parantez içindeki rakamlar o ülkenin ilgili değişkenine ait endeks verisi olduğunu göstermektedir.

Tüm kriterler dikkate alınarak hesaplanan, ülkelerin Çevresel Performans İndeksi 2018 değerleri ve ülke sıralamaları ile çalışma kapsamında önerilen model sonucunda bulunan değerler ve sıralamalar sonuçlar bölümünde karşılaştırmalı bir şekilde incelenecektir. Aralarında istatistiksel bir farklılık olup olmadığı test edilecektir.

\subsection{Entropi Yöntemi İle Kriterlerin Ağırlıklarının Bulunması}

Entropi yöntemi ile kriterlerin ağırlıklarının hesaplanabilmesi için öncelikle Tablo 2'de yer alan karar matrisi (2) no'lu formül yardımıyla normalize edilerek (3) no'lu formül yardımıyla entropi değerleri bulunmuştur. Daha sonra (4) ve (5) no'lu formüller kullanılarak farklılaşma dereceleri ve kriter ağırlıkları bulunmuş olup, sonuçlar Tablo 3'de yer almaktadır. Ormanlar ve su kaynakları değişkenlerine ait verilerde sıfır değeri olduğundan Zhang vd. (2014) tarafından önerilen dönüştürme işlemi gerçekleştirilmiştir. 
Tablo 3: Entropi Yönteminin Sonuçları

\begin{tabular}{|c|c|c|c|c|c|c|c|c|c|c|}
\hline ÜLKELER & C1 & $\mathrm{C2}$ & C3 & C4 & C5 & C6 & C7 & C8 & C9 & C10 \\
\hline AVUSTURYA & $-0,1063$ & $-0,1151$ & $-0,1155$ & $-0,1093$ & $-0,1177$ & $-0,1297$ & $-0,1089$ & $-0,1238$ & $-0,1120$ & 0,1423 \\
\hline BELÇíKA & $-0,1122$ & $-0,1164$ & $-0,0841$ & $-0,1127$ & $-0,0782$ & $-0,0933$ & $-0,1101$ & $-0,1164$ & $-0,1112$ & $-0,1075$ \\
\hline BULGARISTAN & $-0,0932$ & $-0,0940$ & $-0,0998$ & $-0,1108$ & $-0,1369$ & $-0,1146$ & $-0,1004$ & $-0,0872$ & $-0,1078$ & $-0,1010$ \\
\hline HIRVATISTAN & $-0,0888$ & $-0,0928$ & $-0,1126$ & $-0,1123$ & $-0,1368$ & $-0,1044$ & $-0,0983$ & $-0,0751$ & $-0,1018$ & $-0,1076$ \\
\hline KIBRIS & $-0,1112$ & $-0,1132$ & $-0,0933$ & $-0,1006$ & $-0,1414$ & $-0,1017$ & $-0,1131$ & $-0,0832$ & $-0,0956$ & $-0,0225$ \\
\hline ÇEK CUMHURIYETI & $-0,0905$ & $-0,0927$ & $-0,1223$ & $-0,1121$ & $-0,0861$ & $-0,1210$ & $-0,0986$ & $-0,0922$ & $-0,1093$ & $-0,1295$ \\
\hline DANIMARKA & $-0,1214$ & $-0,1178$ & $-0,1130$ & $-0,1117$ & $-0,0673$ & $-0,0991$ & $-0,1147$ & $-0,1079$ & $-0,1115$ & $-0,1364$ \\
\hline ESTONYA & $-0,1032$ & $-0,0813$ & $-0,1135$ & $-0,1099$ & $-0,0307$ & $-0,1318$ & $-0,0688$ & $-0,0889$ & $-0,1099$ & $-0,0961$ \\
\hline FINLANDIYA & $-0,1212$ & $-0,1197$ & $-0,1233$ & $-0,1072$ & $-0,0379$ & $-0,1132$ & $-0,1083$ & $-0,0826$ & $-0,1103$ & $-0,1112$ \\
\hline FRANSA & $-0,1186$ & $-0,1173$ & $-0,1085$ & $-0,1132$ & $-0,1101$ & $-0,1087$ & $-0,1181$ & $-0,1340$ & $-0,1092$ & $-0,1374$ \\
\hline ALMANYA & $-0,1081$ & $-0,1169$ & $-0,1233$ & $-0,1137$ & $-0,1385$ & $-0,0948$ & $-0,0996$ & $-0,1307$ & $-0,1124$ & $-0,1282$ \\
\hline YUNANISTAN & $-0,1127$ & $-0,1197$ & $-0,0863$ & $-0,1086$ & $-0,1343$ & $-0,1166$ & $-0,0815$ & $-0,0792$ & $-0,1109$ & $-0,1105$ \\
\hline MACARISTAN & $-0,0764$ & $-0,0891$ & $-0,1015$ & $-0,1093$ & $-0, c$ & $-0,1$ & $-0,1075$ & $-0,1124$ & 074 & \\
\hline İRLANDA & $-0,1185$ & $-0,1197$ & $-0,0989$ & $-0,1067$ & $-0,0508$ & $-0,1259$ & $-0,0979$ & $-0,1247$ & $-0,1056$ & $-0,1292$ \\
\hline ITALYA & $-0,1048$ & $-0,1197$ & $-0,0960$ & $-0,1114$ & $-0,1274$ & $-0,0802$ & $-0,1118$ & $-0,1260$ & $-0,1108$ & $-0,1097$ \\
\hline LETONYA & $-0,1021$ & $-0,0835$ & $-0,1080$ & $-0,1096$ & $-0,0260$ & $-0,0990$ & $-0,0826$ & $-0,1218$ & $-0,1098$ & $-0,1043$ \\
\hline LITVANYA & $-0,1024$ & $-0,0813$ & $-0,1115$ & $-0,1111$ & $-0,0462$ & $-0,1089$ & $-0,1085$ & $-0,0953$ & $-0,1075$ & $-0,1293$ \\
\hline LÜKSEMBURG & $-0,1166$ & $-0,1191$ & $-0,1133$ & $-0,1134$ & $-0,0895$ & $-0,1230$ & $-0,1036$ & $-0,0977$ & $-0,1125$ & $-0,0914$ \\
\hline MALTA & $-0,1173$ & $-0,1197$ & $-0,0733$ & $-0,1060$ & $-0,2195$ & $-0,1071$ & $-0,1140$ & $-0,0925$ & 127 & $-0,0816$ \\
\hline HOLL & & & & & & & & & & \\
\hline POLC & $-0,0940$ & $-0,0756$ & $-0,0950$ & $-0,1133$ & $-0,0732$ & $-0,0$ & -0 , & 093 & -0 , & $-0,1005$ \\
\hline PORTEKIZ & $-0,1143$ & $-0,1142$ & $-0,0906$ & $-0,1091$ & $-0,0020$ & $-0,0707$ & $-0,1015$ & $-0,1037$ & $-0,1078$ & $-0,0219$ \\
\hline ROMANYA & $-0,0845$ & $-0,0801$ & $-0,0940$ & $-0,1086$ & $-0,1184$ & $-0,0965$ & $-0,1158$ & $-0,1081$ & $-0,0995$ & $-0,1083$ \\
\hline SLOVAKYA & $-0,0840$ & $-0,0924$ & $-0,1121$ & $-0,1115$ & $-0,0836$ & $-0,1310$ & $-0,1225$ & $-0,1169$ & $-0,1046$ & $-0,1286$ \\
\hline SLOVENYA & $-0,0959$ & $-0,0933$ & $-0,1208$ & $-0,1128$ & $-0,1272$ & $-0,1178$ & $-0,0940$ & $-0,0835$ & $-0,1034$ & $-0,0857$ \\
\hline ISPANYA & $-0,1221$ & $-0,1147$ & $-0,0869$ & $-0,1127$ & $-0,0516$ & $-0,0881$ & $-0,1149$ & $-0,1061$ & $-0,1125$ & $-0,0762$ \\
\hline ISVEÇ & $-0,1159$ & $-0,1171$ & $-0,1233$ & $-0,1000$ & $-0,0357$ & $-0,1033$ & $-0,1364$ & $-0,1004$ & $-0,1115$ & $-0,1192$ \\
\hline BİRLEŞİK KRALLIK & $-0,1173$ & $-0,1197$ & $-0,1173$ & $-0,1135$ & $-0,0423$ & $-0,0866$ & $-0,1092$ & $-0,1203$ & $-0,1126$ & $-0,1225$ \\
\hline TÜRKIYE & $-0,1026$ & $-0,0821$ & $-0,0844$ & $-0,0412$ & $-0,1171$ & $-0,0812$ & $-0,0784$ & $-0,0766$ & $-0,1064$ & $-0,0952$ \\
\hline MAKEDONYA & $-0,0912$ & $-0,0920$ & $-0,0958$ & $-0,0851$ & $-0,1265$ & $-0,1079$ & $-0,1102$ & $-0,0921$ & $-0,0702$ & $-0,0878$ \\
\hline ARNAVUTLUK & $-0,0902$ & $-0,0894$ & $-0,0885$ & $-0,0950$ & $-0,1047$ & $-0,1094$ & $-0,1156$ & $-0,1236$ & $-0,0968$ & $-0,0620$ \\
\hline SIRBISTAN & $-0,0811$ & $-0,0925$ & $-0,0943$ & $-0,0699$ & $-0,1481$ & $-0,1053$ & $-0,1076$ & $-0,0953$ & $-0,0784$ & $-0,1159$ \\
\hline BOSNA HERSEK & $-0,0850$ & $-0,0942$ & $-0,0891$ & $-0,0435$ & $-0,1735$ & $-0,0625$ & $-0,0579$ & $-0,0581$ & $-0,0013$ & $-0,0825$ \\
\hline KARADAĞ & $-0,0940$ & $-0,1009$ & $-0,1053$ & $-0,0935$ & $-0,1269$ & $-0,0773$ & $-0,0881$ & $-0,0947$ & $-0,0976$ & $-0,0342$ \\
\hline$e j$ & 0,9955 & 0,9940 & 0,9953 & 0,9921 & 0,9384 & 0,9917 & 0,9939 & 0,9909 & 0,9897 & 0,9761 \\
\hline$d j$ & 0,0045 & 0,0060 & 0,0047 & 0,0079 & 0,0616 & 0,0083 & 0,0061 & 0,0091 & 0,0103 & 0,0239 \\
\hline$w j$ & 0,0317 & 0,0419 & 0,0328 & 0,0553 & 0,4329 & 0,0581 & 0,0427 & 0,0640 & 0,0726 & 0,1681 \\
\hline
\end{tabular}

Tablo 3 incelendiğinde; Entropi yöntemine göre en önemli değişkeninin ormanlar değişkeni olduğu bu değişkeni tarım, su kaynakları, hava kirliliği ve balıkçılık değişkenlerinin izlediği, en az öneme sahip değişkenlerin ise hava kalitesi, su kalitesi ve ağır metaller değişkenleri olduğu görülmektedir.

\subsection{GiA İle Ülkelerin Çevresel Performansının Ölçülmesi}

GIA ile ülkelerin çevresel performansı hem Entropi ile bütünleşik olarak hem de kriter ağırlıkları eşit önem düzeyinde alınarak ölçülmüştür. Bunun için öncelikle Tablo 2'de yer alan karar matrisi (11) no'lu formül ile normalize edilmiş, (15) no'lu formülle fark matrisi oluşturulmuş ve (17)-(20) no'lu formüller yardımıyla da gri ilişkisel dereceler hem Entropi yönteminden elde edilen kriter ağılıkları hem de eşit önem seviyesinde kriter ağırlıkları dikkate alınarak hesaplanmış ve Tablo 4'de analiz sonuçları yer almaktadır. 
Eskişehir Osmangazi Üniversitesi iißBF Dergisi

Tablo 4: GiA Analiz Sonuçları

\begin{tabular}{|c|c|c|c|c|c|c|c|c|c|c|c|c|c|c|}
\hline \multicolumn{11}{|c|}{ Gri ilişkisel Katsayı Matrisi } & \multicolumn{2}{|c|}{ Entropi-GiA } & \multicolumn{2}{|c|}{$\begin{array}{l}\text { Kriterleri Eşit } \\
\text { Ağırlıklı-GiA }\end{array}$} \\
\hline ÜLKELER & C1 & C2 & C3 & C4 & C5 & C6 & C7 & $\mathrm{C8}$ & C9 & C10 & $\Gamma 0 i$ & Sira & $\Gamma 0 i$ & Sira \\
\hline AVUSTURYA & 0,572 & 0,813 & 0,741 & 0,872 & 0,446 & 0,933 & 0,555 & 0,758 & 0,981 & 1,000 & 0,684 & 2 & 0,767 & 2 \\
\hline BELÇiKA & 0,677 & 0,857 & 0,382 & 0,967 & 0,389 & 0,453 & 0,566 & 0,649 & 0,963 & 0,578 & 0,551 & 18 & 648 & 16 \\
\hline BULGARISTAN & 0,430 & 0,449 & 0,497 & 0,910 & 0,487 & 0,637 & 0,493 & 0,429 & 0,891 & 541 & 0,551 & 7 & 577 & 23 \\
\hline HIRVATISTAN & 0,399 & 0,439 & 0,678 & 0,955 & 0,487 & 0,531 & 0,480 & 0,381 & 0,788 & ,579 & 0,547 & 9 & ,572 & 25 \\
\hline KIBRIS & 0,656 & 0,754 & 0,441 & 0,701 & 0,498 & 0,509 & 0,593 & 0,411 & 0,707 & 0,334 & 0,510 & 26 &, 560 & 26 \\
\hline $\begin{array}{c}\text { ÇEK } \\
\text { CUMHURIYETi }\end{array}$ & 0,410 & 0,438 & 0,956 & 0,948 & 0 & 0,734 & 0 & 0 & 0 & 0 & 0 & 13 & 2 & 5 \\
\hline DANIMARKA & 0,966 & 0,913 & 0,686 & 0,936 & 0,377 & 0,491 & 0,609 & 0,561 & 0,969 & 0,883 & 0,615 & 5 & 0,739 & 4 \\
\hline ESTONYA & 0,530 & 0,361 & 0,696 & 0,887 & 0,347 & 1,000 & 0,360 & 0,437 & 0,933 & 0,516 & 0,510 & 2 & 607 & 20 \\
\hline FINLANDIYA & 0,959 & 1,000 & 1,000 & 0,823 & 0,352 & 0,620 & 0,550 & 0,408 & 0,943 & 0,604 & 0,559 & 16 & 726 & 7 \\
\hline FRANSA & 0,855 & 0,894 & 0,605 & 0,981 & 0,433 & 0,571 & 0,647 & 1,000 & 0,918 & 0,901 & 0,669 & 3 & 80 & 1 \\
\hline ALMANYA & 0,599 & 0,878 & 1,000 & 1,000 & 0,491 & 0,462 & 0,489 & 0,903 & 0,993 & 0,763 & 0,662 & 4 & 58 & 3 \\
\hline YUNANISTAN & 0,688 & 1,000 & 0,395 & 0,856 & 0,481 & 0,664 & 0,402 & 0,395 & 0,956 & 0,599 & 0,583 & 12 & 643 & 17 \\
\hline MACARISTAN & 0,333 & 0,410 & 0,515 & 0,873 & 0,373 & 0,802 & 0,544 & 0,604 & 0,883 & 0,937 & 0,584 & 11 & 627 & 18 \\
\hline İRLANDA & 0,849 & 1,000 & 0,488 & 0,812 & 0,362 & 0,832 & 0,478 & 0,774 & 0,850 & 0,776 & 0,597 & 6 & 0,722 & 8 \\
\hline ITALYA & 0,550 & 1,000 & 0,462 & 0,927 & 0,466 & 0,390 & 0,580 & 0,799 & 0,952 & 0,593 & 0,595 & 7 & 0,672 & 13 \\
\hline LETONYA & 0,516 & 0,373 & 0,598 & 0,880 & 0,345 & 0,490 & 0,405 & 0,725 & 0,931 & 0,559 & 0,503 & 27 & 0,582 & 22 \\
\hline LITVANYA & 0,519 & 0,361 & 0,657 & 0,920 & 0,358 & 0,572 & 0,552 & 0,470 & 0,884 & 0,777 & 0,541 & 20 & 0,607 & 19 \\
\hline LÜKSEMBURG & 0,789 & 0,971 & 0,691 & 0,989 & 0,402 & 0,770 & 0,514 & 0,485 & 0,995 & 0,495 & 0,570 & 15 & 0,710 & 9 \\
\hline MALTA & 0,809 & 1,000 & 0,333 & 0,796 & 1,000 & 0,555 & 0,602 & 0,455 & 1,000 & 0,457 & 0,792 & 1 & 0,701 & 10 \\
\hline HOLLANDA & 0,698 & 0,931 & 0,715 & 0,681 & 0,496 & 0,370 & 0,466 & 0,992 & 0,998 & 0,475 & 0,594 & 8 & 0,682 & 11 \\
\hline POLONYA & 0,436 & 0,333 & 0,454 & 0,984 & 0,383 & 0,422 & 0,571 & 0,573 & 0,867 & 0,538 & 0,502 & 28 & 0,556 & 27 \\
\hline PORTEKIZ & 0,725 & 0,785 & 0,422 & 0,866 & 0,333 & 0,357 & 0,500 & 0,526 & 0,890 & 0,333 & 0,458 & 34 & 0,574 & 24 \\
\hline ROMANYA & 0,372 & 0,355 & 0,446 & 0,854 & 0,447 & 0,473 & 0,621 & 0,563 & 0,757 & 0,584 & 0,525 & 22 & 0,547 & 28 \\
\hline SLOVAKYA & 0,370 & 0,435 & 0,667 & 0,932 & 0,395 & 0,971 & 0,704 & 0,656 & 0,832 & 0,768 & 0,592 & 9 & 0,673 & 12 \\
\hline SLOVENYA & 0,453 & 0,443 & 0,895 & 0,969 & 0,465 & 0,682 & 0,457 & 0,412 & 0,813 & 0,472 & 0,541 & 21 & 0,606 & 21 \\
\hline ISPANYA & 1,000 & 0,798 & 0,398 & 0,966 & 0,363 & 0,425 & 0,611 & 0,545 & 0,994 & 0,439 & 0,520 & 24 & 0,654 & 14 \\
\hline ISVEEÇ & 0,769 & 0,882 & 1,000 & 0,692 & 0,351 & 0,522 & 1,000 & 0,502 & 0,970 & 0,667 & 0,572 & 14 & 0,736 & 5 \\
\hline BİRLEŞIK KRALLIK & 0,810 & 1,000 & 0,787 & 0,993 & 0,355 & 0,418 & 0,558 & 0,703 & 0,996 & 0,699 & 0,585 & 10 & 0,732 & 6 \\
\hline TÜRKIYE & 0,522 & 0,365 & 0,384 & 0,333 & 0,445 & 0,394 & 0,390 & 0,386 & 0,865 & 0,512 & 0,469 & 33 & 0,460 & 33 \\
\hline MAKEDONYA & 0,415 & 0,432 & 0,461 & 0,528 & 0,464 & 0,562 & 0,566 & 0,453 & 0,510 & 0,480 & 0,480 & 31 & 0,487 & 32 \\
\hline ARNAVUTLUK & 0,408 & 0,412 & 0,408 & 0,624 & 0,424 & 0,578 & 0,619 & 0,754 & 0,721 & 0,401 & 0,490 & 29 & 0,535 & 29 \\
\hline SIRBISTAN & 0,355 & 0,436 & 0,448 & 0,432 & 0,517 & 0,539 & 0,545 & 0,471 & 0,558 & 0,639 & 0,524 & 23 & 0,494 & 31 \\
\hline BOSNA HERSEK & 0,375 & 0,452 & 0,411 & 0,338 & 0,609 & 0,333 & 0,333 & 0,333 & 0,333 & 0,460 & 0,483 & 30 & 0,398 & 34 \\
\hline KARADAĞ & 0,437 & 0,523 & 0,560 & 0,607 & 0,464 & 0,379 & 0,428 & 0,467 & 0,731 & 0,349 & 0,471 & 32 & 0,495 & 30 \\
\hline
\end{tabular}

Entropi-GiA modeline göre en iyi performans gösteren ülkelerin Malta, Avusturya ve Fransa, performansı en düşük ülkelerin ise Portekiz, Türkiye ve Karadağ olduğu görülmektedir. Kriterleri eşit ağırlıklı GiA modeline göre de performansı en yüksek ülkeler, Fransa, Avusturya ve Almanya, performansı en düşük ülkeler ise Bosna Hersek, Türkiye ve Makedonya olarak belirlenmiştir. 


\subsection{MOORA Yöntemiyle Ülkelerin Çevresel Performansının Ölçülmesi}

MOORA yöntemlerinden MOORA Oran yaklaşımı, Entropi-MOORA Önem Katsayısı, Kriterleri Eşit Ağılıklı MOORA Referans Nokta Yaklaşımı ve Entropi-MOORA Referans Nokta Yaklaşımı ile 4 farklı ÇKKV modeli oluşturulmuştur. Eşitlik (23) ile Tablo 2'de yer alan karar matrisi normalize edilmiş ve (24) no'lu formül ile MOORA Oran Yaklaşımı sonuçları hesaplanmıştır. (25) no'lu formül ile Entropi ile elde edilen kriter ağırlıkları kullanılarak MOORA Önem Katsayısı modeli hesaplanmıştır. (27) ve (28) no'lu formüller yardımıyla da hem eşit önem ağırlıklı hem de Entropi ile elde edilen kriter ağırlıkları dikkate alınarak MOORA Referans Nokta Yaklaşımı sonuçları elde edilmiştir. 4 farklı modele ait tüm sonuçlar Tablo 5'de yer almaktadır.

Tablo 5: MOORA Yöntemleri Analiz Sonuçları

\begin{tabular}{|c|c|c|c|c|c|c|c|c|}
\hline \multirow[t]{2}{*}{ ÜLKELER } & \multicolumn{2}{|c|}{$\begin{array}{l}\text { MOORA ORAN } \\
\text { YAKLAŞIMI }\end{array}$} & \multicolumn{2}{|c|}{$\begin{array}{l}\text { ENTROPI-MOORA } \\
\text { ÖNEM KATSAYISI } \\
\text { YAKLAŞIMI }\end{array}$} & \multicolumn{2}{|c|}{$\begin{array}{c}\text { KRITERLERI EŞIT AĞIRLIKLI } \\
\text { MOORA REFERANS NOKTA } \\
\text { YAKLAŞIMI }\end{array}$} & \multicolumn{2}{|c|}{$\begin{array}{c}\text { ENTROPI-MOORA } \\
\text { REFERANS NOKTA } \\
\text { YAKLAŞIMI } \\
\end{array}$} \\
\hline & $\mathbf{Y i}$ & Sira & $\mathbf{Y i}$ & Sira & $\mathbf{Y i}$ & Sira & $\mathbf{Y i}$ & Sira \\
\hline AVUSTURYA & 1,982 & 1 & 0,195 & 3 & 0,280 & 15 & 0,121 & 15 \\
\hline BELÇIKKA & 1,675 & 16 & 0,141 & 24 & 0,354 & 22 & 0,153 & 22 \\
\hline BULGARISTAN & 1,666 & 17 & 0,184 & 8 & 0,237 & 7 & 0,103 & 7 \\
\hline HIRVATISTAN & 1,636 & 20 & 0,183 & 11 & 0,237 & 8 & 0,103 & 8 \\
\hline KIBRIS & 1,555 & 24 & 0,165 & 14 & 0,231 & 5 & 0,098 & 4 \\
\hline ÇEK CUMHURIYETI & 1,702 & 14 & 0,154 & 17 & 0,341 & 20 & 0,147 & 20 \\
\hline DANIMARKA & 1,818 & 5 & 0,148 & 18 & 0,372 & 24 & 0,161 & 24 \\
\hline ESTONYA & 1,482 & 29 & 0,103 & 33 & 0,423 & 32 & 0,183 & 32 \\
\hline FINLANDIYA & 1,695 & 15 & 0,118 & 30 & 0,414 & 30 & 0,179 & 30 \\
\hline FRANSA & 1,971 & 2 & 0,187 & 6 & 0,295 & 17 & 0,128 & 17 \\
\hline ALMANYA & 1,945 & 4 & 0,206 & 2 & 0,233 & 6 & 0,101 & 6 \\
\hline YUNANISTAN & 1,707 & 13 & 0,186 & 7 & 0,243 & 9 & 0,105 & 9 \\
\hline MACARISTAN & 1,665 & 18 & 0,142 & 23 & 0,379 & 25 & 0,164 & 25 \\
\hline İRLANDA & 1,780 & 8 & 0,136 & 25 & 0,397 & 27 & 0,172 & 27 \\
\hline ITALYA & 1,788 & 6 & 0,184 & 9 & 0,259 & 10 & 0,112 & 10 \\
\hline LETONYA & 1,505 & 28 & 0,104 & 32 & 0,429 & 33 & 0,186 & 33 \\
\hline LITVANYA & 1,608 & 21 & 0,125 & 28 & 0,403 & 28 & 0,175 & 28 \\
\hline LÜKSEMBURG & 1,758 & 11 & 0,148 & 19 & 0,334 & 19 & 0,145 & 19 \\
\hline MALTA & 1,949 & 3 & 0,284 & 1 & 0,137 & 1 & 0,023 & 1 \\
\hline HOLLANDA & 1,778 & 9 & 0,189 & 5 & 0,229 & 4 & 0,099 & 5 \\
\hline POLONYA & 1,508 & 27 & 0,129 & 26 & 0,363 & 23 & 0,157 & 23 \\
\hline PORTEKIZ & 1,334 & 32 & 0,069 & 34 & 0,451 & 34 & 0,195 & 34 \\
\hline ROMANYA & 1,598 & 22 & 0,167 & 13 & 0,278 & 14 & 0,120 & 14 \\
\hline SLOVAKYA & 1,780 & 7 & 0,157 & 16 & 0,345 & 21 & 0,149 & 21 \\
\hline SLOVENYA & 1,648 & 19 & 0,170 & 12 & 0,259 & 11 & 0,112 & 11 \\
\hline ISPANYA & 1,576 & 23 & 0,112 & 31 & 0,396 & 26 & 0,171 & 26 \\
\hline ISVEÇ & 1,762 & 10 & 0,122 & 29 & 0,417 & 31 & 0,180 & 31 \\
\hline BIIRLEŞIK KRALLIK & 1,749 & 12 & 0,127 & 27 & 0,408 & 29 & 0,177 & 29 \\
\hline TÜRKIYE & 1,296 & 33 & 0,147 & 21 & 0,281 & 16 & 0,122 & 16 \\
\hline MAKEDONYA & 1,480 & 30 & 0,161 & 15 & 0,261 & 13 & 0,113 & 13 \\
\hline ARNAVUTLUK & 1,528 & 26 & 0,143 & 22 & 0,306 & 18 & 0,132 & 18 \\
\hline SIRBISTAN & 1,548 & 25 & 0,191 & 4 & 0,211 & 3 & 0,091 & 3 \\
\hline BOSNA HERSEK & 1,127 & 34 & 0,183 & 10 & 0,189 & 2 & 0,062 & 2 \\
\hline KARADAĞ & 1,403 & 31 & 0,147 & 20 & 0,260 & 12 & 0,112 & 12 \\
\hline
\end{tabular}

Tablo 5 incelendiğinde; en iyi performans gösteren ülkeler MOORA Oran Yaklaşımına göre Avusturya, Fransa ve Malta, Entropi-MOORA Önem Katsayısı Yaklaşımına göre Malta, Almanya ve Avusturya'dır. Ayrıca Kriterleri Eşit Ağırlıklı MOORA Referans Nokta Yaklaşımı ile EntropiMOORA Referans Nokta Yaklaşımına göre Malta, Bosna Hersek ve Sırbistan'ın en iyi performans gösteren ülkeler olduğu görülmektedir. 


\section{4. ÇKKV Modeli Sonuçlarının Bulanık Mantık Yaklaşımıyla Bütünleştirilmesi}

ÇKKV yöntemleri ile problem çözümünde kullanılan yöntemin teorik temeline, bilimsel altyapısına ve uygulama aşamalarına bağlı olarak farklı sonuçlar elde edilebilmektedir. Bu çalışmada da geliştirilen 6 farklı ÇKKV modelinin sonuçlarının birbirlerinden farklı olduğu, ülke sıralamalarının kullanılan yönteme göre değiştiği gözlemlenmektedir. Tüm bu sonuçları bütünleştirebilmek, tek bir ülke performans değeri bulabilmek için bulanık mantık tabanlı bir yaklaşım önerilmiştir. Bu yaklaşımda öncelikle bulunan tüm modellere ait sonuçlar bir karar matrisinde birleştirilir ve sütun toplamları "1" olacak şekilde normalize edilir. Tablo 6'da normalize karar matrisi yer almaktadır.

Tablo 6: Normalize Karar Matrisi

\begin{tabular}{|c|c|c|c|c|c|c|}
\hline ÜLKELER & $\begin{array}{l}\text { ENTROPI- } \\
\text { GIA }\end{array}$ & $\begin{array}{c}\text { KRiTERLERi } \\
\text { EŞiT AĞIRLIKLI } \\
\text { GIA }\end{array}$ & $\begin{array}{l}\text { MOORA ORAN } \\
\text { YAKLAŞIMI }\end{array}$ & $\begin{array}{c}\text { ENTROPI-MOORA } \\
\text { ÖNEM KATSAYISI } \\
\text { YAKLAŞIMI }\end{array}$ & $\begin{array}{c}\text { KRITERLERI EŞiT } \\
\text { AĞIRLIKLI MOORA } \\
\text { REFERANS NOKTA } \\
\text { YAKLAŞIMI }\end{array}$ & $\begin{array}{c}\text { ENTROPI-MOORA } \\
\text { REFERANS NOKTA } \\
\text { YAKLAŞIMI }\end{array}$ \\
\hline AVUSTURYA & 0,0360 & 0,0361 & 0,0354 & 0,0368 & 0,0262 & 0,0266 \\
\hline BELÇiKA & 0,0290 & 0,0305 & 0,0299 & 0,0267 & 0,0333 & 0,0337 \\
\hline BULGARISTAN & 0,0290 & 0,0271 & 0,0298 & 0,0347 & 0,0223 & 0,0226 \\
\hline HIRVATISTAN & 0,0288 & 0,0269 & 0,0292 & 0,0345 & 0,0223 & 0,0226 \\
\hline KIBRIS & 0,0268 & 0,0263 & 0,0278 & 0,0311 & 0,0217 & 0,0216 \\
\hline $\begin{array}{l}\text { ÇEK } \\
\text { CUMHURIYETI }\end{array}$ & 0,0304 & 0,0306 & 0,0304 & 0,0290 & 0,0320 & 0,0324 \\
\hline DANIMARKA & 0,0324 & 0,0347 & 0,0325 & 0,0279 & 0,0349 & 0,0354 \\
\hline ESTONYA & 0,0268 & 0,0285 & 0,0265 & 0,0194 & 0,0397 & 0,0402 \\
\hline FINLANDIYA & 0,0294 & 0,0341 & 0,0303 & 0,0222 & 0,0389 & 0,0394 \\
\hline FRANSA & 0,0352 & 0,0367 & 0,0352 & 0,0352 & 0,0277 & 0,0281 \\
\hline ALMANYA & 0,0348 & 0,0356 & 0,0347 & 0,0389 & 0,0219 & 0,0222 \\
\hline YUNANISTAN & 0,0307 & 0,0302 & 0,0305 & 0,0350 & 0,0228 & 0,0231 \\
\hline MACARISTAN & 0,0307 & 0,0295 & 0,0297 & 0,0268 & 0,0356 & 0,0360 \\
\hline İRLANDA & 0,0314 & 0,0339 & 0,0318 & 0,0257 & 0,0372 & 0,0377 \\
\hline ITTALYA & 0,0313 & 0,0316 & 0,0319 & 0,0347 & 0,0243 & 0,0246 \\
\hline LETONYA & 0,0265 & 0,0274 & 0,0269 & 0,0197 & 0,0402 & 0,0407 \\
\hline LITVANYA & 0,0285 & 0,0285 & 0,0287 & 0,0235 & 0,0378 & 0,0383 \\
\hline LÜKSEMBURG & 0,0300 & 0,0334 & 0,0314 & 0,0279 & 0,0314 & 0,0318 \\
\hline MALTA & 0,0416 & 0,0329 & 0,0348 & 0,0535 & 0,0129 & 0,0051 \\
\hline HOLLANDA & 0,0313 & 0,0321 & 0,0318 & 0,0356 & 0,0215 & 0,0217 \\
\hline POLONYA & 0,0264 & 0,0261 & 0,0269 & 0,0242 & 0,0340 & 0,0345 \\
\hline PORTEKIZ & 0,0241 & 0,0270 & 0,0238 & 0,0129 & 0,0424 & 0,0429 \\
\hline ROMANYA & 0,0276 & 0,0257 & 0,0285 & 0,0315 & 0,0261 & 0,0264 \\
\hline SLOVAKYA & 0,0312 & 0,0316 & 0,0318 & 0,0295 & 0,0324 & 0,0328 \\
\hline SLOVENYA & 0,0285 & 0,0285 & 0,0294 & 0,0320 & 0,0243 & 0,0246 \\
\hline ISPANYA & 0,0274 & 0,0307 & 0,0281 & 0,0211 & 0,0371 & 0,0376 \\
\hline ISVEÇ & 0,0301 & 0,0346 & 0,0315 & 0,0230 & 0,0391 & 0,0396 \\
\hline BİRLEŞIK KRALLIK & 0,0308 & 0,0344 & 0,0312 & 0,0239 & 0,0383 & 0,0388 \\
\hline TÜRKIYE & 0,0247 & 0,0216 & 0,0232 & 0,0276 & 0,0264 & 0,0267 \\
\hline MAKEDONYA & 0,0252 & 0,0229 & 0,0264 & 0,0303 & 0,0245 & 0,0248 \\
\hline ARNAVUTLUK & 0,0258 & 0,0251 & 0,0273 & 0,0269 & 0,0287 & 0,0291 \\
\hline SIRBISTAN & 0,0276 & 0,0232 & 0,0276 & 0,0360 & 0,0198 & 0,0200 \\
\hline BOSNA HERSEK & 0,0254 & 0,0187 & 0,0201 & 0,0346 & 0,0177 & 0,0137 \\
\hline KARADAĞ & 0,0248 & 0,0232 & 0,0250 & 0,0277 & 0,0244 & 0,0247 \\
\hline
\end{tabular}

Normalize karar matrisi elde edildikten sonra her bir sütun (model) tek tek ele alınarak normalize değerler küçükten büyüğe doğru sıralanır. Bu sıralanan değerler Tablo 7'de yer alan bulanık kümeler dikkate alınarak 5 sınıfa ayrılır. Bulanık değerler olarak üçgen bulanık sayılar kullanılmıştır. Kümülatif toplamları 0,20 oluncaya kadar olan tüm değerler "Çok Kötü", 0,200,40 arası değerler "Kötü", 0,40-0,60 arasındaki değerler "Orta", 0,60-0,80 arasındaki değerler "İyi" ve 0,80-1,00 arasındaki değerler de "Çok İyi" sınıfına dahil edilmektedir. 
Tablo 7: Bulanık Kümeler

\begin{tabular}{ll}
\hline Çok İyi (Çi) & $(0.8,1.0,1.0)$ \\
İyi (i) & $(0.6,0.8,1.0)$ \\
Orta (O) & $(0.4,0.6,0.8)$ \\
Kötü (K) & $(0.2,0.4,0.6)$ \\
Çok Kötü (ÇK) & $(0.0,0.0,0.2)$ \\
\hline
\end{tabular}

Tablo 8'de ise normalize edilen değerlerin bulanık kümeleri gösterilmektedir.

Tablo 8: Normalize Değerlerin Bulanık Kümelere Dönüştürülmesi

\begin{tabular}{|c|c|c|c|c|c|c|c|c|c|c|c|}
\hline 1. MODEL & SINIF & 2. MODEL & SINIF & 3. MODEL & SINIF & 4. MODEL & SINIF & 5. MODEL & SINIF & 6. MODEL & SINIF \\
\hline 0,0241 & \multirow{8}{*}{ ÇK } & 0,0187 & \multirow{9}{*}{ ÇK } & 0,0201 & \multirow{9}{*}{ ÇK } & 0,0129 & \multirow{10}{*}{ ÇK } & 0,0129 & \multirow{10}{*}{ ÇK } & 0,0051 & \multirow{11}{*}{ ÇK } \\
\hline 0,0247 & & 0,0216 & & 0,0232 & & 0,0194 & & 0,0177 & & 0,0137 & \\
\hline 0,0248 & & 0,0229 & & 0,0238 & & 0,0197 & & 0,0198 & & 0,0200 & \\
\hline 0,0252 & & 0,0232 & & 0,0250 & & 0,0211 & & 0,0215 & & 0,0216 & \\
\hline 0,0254 & & 0,0232 & & 0,0264 & & 0,0222 & & 0,0217 & & 0,0217 & \\
\hline 0,0258 & & 0,0251 & & 0,0265 & & 0,0230 & & 0,0219 & & 0,0222 & \\
\hline 0,0264 & & 0,0257 & & 0,0269 & & 0,0235 & & 0,0223 & & 0,0226 & \\
\hline 0,0265 & & 0,0261 & & 0,0269 & & 0,0239 & & 0,0223 & & 0,0226 & \\
\hline 0,0268 & \multirow{7}{*}{ K } & 0,0263 & & 0,0273 & & 0,0242 & & 0,0228 & & 0,0231 & \\
\hline 0,0268 & & 0,0269 & \multirow{7}{*}{ K } & 0,0276 & & 0,0257 & & 0,0243 & & 0,0246 & \\
\hline 0,0274 & & 0,0270 & & 0,0278 & & 0,0267 & \multirow{7}{*}{ K } & 0,0243 & \multirow{8}{*}{ K } & 0,0246 & \\
\hline 0,0276 & & 0,0271 & & 0,0281 & & 0,0268 & & 0,0244 & & 0,0247 & \multirow{7}{*}{ K } \\
\hline 0,0276 & & 0,0274 & & 0,0285 & K & 0,0269 & & 0,0245 & & 0,0248 & \\
\hline 0,0285 & & 0,0285 & & 0,0287 & & 0,0276 & & 0,0261 & & 0,0264 & \\
\hline 0,0285 & & 0,0285 & & 0,0292 & & 0,0277 & & 0,0262 & & 0,0266 & \\
\hline 0,0288 & \multirow{7}{*}{0} & 0,0285 & & 0,0294 & & 0,0279 & & 0,0264 & & 0,0267 & \\
\hline 0,0290 & & 0,0295 & \multirow{7}{*}{$\mathrm{O}$} & 0,0297 & \multirow{6}{*}{0} & 0,0279 & & 0,0277 & & 0,0281 & \\
\hline 0,0290 & & 0,0302 & & 0,0298 & & 0,0290 & \multirow{6}{*}{$\mathrm{O}$} & 0,0287 & & 0,0291 & \\
\hline 0,0294 & & 0,0305 & & 0,0299 & & 0,0295 & & 0,0314 & \multirow{6}{*}{0} & 0,0318 & \multirow{6}{*}{0} \\
\hline 0,0300 & & 0,0306 & & 0,0303 & & 0,0303 & & 0,0320 & & 0,0324 & \\
\hline 0,0301 & & 0,0307 & & 0,0304 & & 0,0311 & & 0,0324 & & 0,0328 & \\
\hline 0,0304 & & 0,0316 & & 0,0305 & & 0,0315 & & 0,0333 & & 0,0337 & \\
\hline 0,0307 & \multirow{7}{*}{ i } & 0,0316 & & 0,0312 & \multirow{6}{*}{$\mathrm{i}$} & 0,0320 & & 0,0340 & & 0,0345 & \\
\hline 0,0307 & & 0,0321 & \multirow{6}{*}{$i$} & 0,0314 & & 0,0345 & \multirow{6}{*}{ j } & 0,0349 & & 0,0354 & \\
\hline 0,0308 & & 0,0329 & & 0,0315 & & 0,0346 & & 0,0356 & \multirow{5}{*}{1} & 0,0360 & \\
\hline 0,0312 & & 0,0334 & & 0,0318 & & 0,0347 & & 0,0371 & & 0,0376 & \\
\hline 0,0313 & & 0,0339 & & 0,0318 & & 0,0347 & & 0,0372 & & 0,0377 & i \\
\hline 0,0313 & & 0,0341 & & 0,0318 & & 0,0350 & & 0,0378 & & 0,0383 & \\
\hline 0,0314 & & 0,0344 & & 0,0319 & \multirow{6}{*}{ çi } & 0,0352 & & 0,0383 & & 0,0388 & \\
\hline 0,0324 & \multirow{5}{*}{ çi } & 0,0346 & & 0,0325 & & 0,0356 & \multirow{5}{*}{ çi } & 0,0389 & & 0,0394 & \multirow{5}{*}{ çi } \\
\hline 0,0348 & & 0,0347 & & 0,0347 & & 0,0360 & & 0,0391 & & 0,0396 & \\
\hline 0,0352 & & 0,0356 & çi & 0,0348 & & 0,0368 & & 0,0397 & çi & 0,0402 & \\
\hline 0,0360 & & 0,0361 & & 0,0352 & & 0,0389 & & 0,0402 & & 0,0407 & \\
\hline 0,0416 & & 0,0367 & & 0,0354 & & 0,0535 & & 0,0424 & & 0,0429 & \\
\hline
\end{tabular}

1. Model: Entropi-GiA, 2. Model: Kriterleri Eşit Ağırıkı GiA, 3. Model: Kriterleri Eşit Ağırlıklı MOORA Oran Yaklaşımı, 4. Model: ENTROPI-MOORA Önem Katsayısı Yaklaşımı, 5. Model: Kriterleri Eşit Ağırıklı MOORA Referans Nokta Yaklaşımı, 6. Model: ENTROPI-MOORA Referans Nokta Yaklaşımı 
Her bir değerin karşılık geldiği bulanık küme değerleri elde edildikten sonra Tablo 9'da yer alan bulanık küme matrisi oluşturulur. Bu matrisin satırları toplanarak bulanık toplam değerler elde edilir. Son aşamada ise üçgen bulanık sayılar ortalama yöntemi ile durulaştırılarak her bir ülkenin performans değeri elde edilmiş olur.

Tablo 9: Bulanık Küme Matrisi ve Ülkelerin Performans Değerleri

\begin{tabular}{|c|c|c|c|c|c|c|c|c|c|}
\hline ÜLKELER & 1. MODEL & ODEL & 3. MODEL & ODEL & 5. MODEL & 6. MODEL & $\begin{array}{c}\text { BULANIK } \\
\text { TOPLAM } \\
\text { DEĞERLER }\end{array}$ & $\begin{array}{c}\text { DURU } \\
\text { DEĞERLER }\end{array}$ & SIRA \\
\hline AVUSTURYA & $(0.8,1.0,1.0)$ & $(0.8,1.0,1.0)$ & $(0.8,1.0,1.0)$ & $(0.8,1.0,1.0)$ & $(0.2,0.4,0.6)$ & $(0.2,0.4,0.6)$ & $(3.6,4.8,5.2)$ & 4,533 & 1 \\
\hline BELÇіKA & $(0.4,0.6,0.8)$ & $(0.4,0.6,0.8)$ & $(0.4,0.6,0.8)$ & $(0.2,0.4,0.6)$ & $(0.4,0.6,0.8)$ & $(0.4,0.6,0.8)$ & $(2.2,3.4,4.6)$ & 3,400 & 16 \\
\hline BULGARISTAN & $(0.4,0.6,0.8)$ & $(0.2,0.4,0.6)$ & $(0.4,0.6,0.8)$ & $(0.6,0.8,1.0)$ & $(0.0,0.0,0.2)$ & $(0.0,0.0,0.2)$ & $(1.6,2.4,3.6)$ & 2,533 & 21 \\
\hline HIRVATISTAN & $(0.4,0.6,0.8)$ & $(0.2,0.4,0.6)$ & $(0.2,0.4,0.6)$ & $(0.6,0.8,1.0)$ & $(0.0,0.0,0.2)$ & $(0.0,0.0,0.2)$ & $(1.4,2.2,3.4)$ & 2,333 & 24 \\
\hline KIBRIS & $(0.2,0.4,0.6)$ & $(0.0,0.0,0.2)$ & $(0.2,0.4,0.6)$ & $(0.4,0.6,0.8)$ & $(0.0,0.0,0.2)$ & $(0.0,0.0,0.2)$ & $(0.8,1.4,2.6)$ & 1,600 & 28 \\
\hline $\begin{array}{l}\text { ÇEK } \\
\text { CUMHURIYETI }\end{array}$ & $(0.4,0.6,0.8)$ & $(0.4,0.6,0$ & $(0.4,0.6$, & 10 & $(0$. & (C & $(2$ & 3, & 13 \\
\hline DANIMARKA & $(0.8,1.0,1.0)$ & $(0.8,1.0,1.0)$ & $(0.8,1.0,1.0)$ & $(0.2,0.4,0.6)$ & $(0.4,0.6,0.8)$ & $(0.4,0.6,0.8)$ & $(3.4,4.6,5.2)$ & 4,400 & 2 \\
\hline ESTONYA & $(0.2,0.4,0.6)$ & $(0.2,0.4,0.6)$ & $(0.0,0.0,0.2)$ & $(0.0,0.0,0.2)$ & $(0.8,1.0,1.0)$ & $(0.8,1.0,1.0)$ & $(2.0,2.8,3.6)$ & 2,8000 & 20 \\
\hline FINLANDIYA & $(0.4,0.6,0.8)$ & $(0.6,0.8,1.0)$ & $(0.4,0.6,0.8)$ & $(0.0,0.0,0.2)$ & $(0.8,1.0,1.0)$ & $(0.8,1.0,1.0)$ & $(3.0,4 \cdot 0,4.8)$ & 3,933 & 9 \\
\hline FRANSA & $(0.8,1.0,1.0)$ & $(0.8,1.0,1.0)$ & $(0.8,1.0,1.0)$ & $(0.6,0.8,1.0)$ & $(0.2,0.4,0.6)$ & $(0.2,0.4,0.6)$ & $(3.4,4.6,5.2)$ & 4,400 & 2 \\
\hline ALMANYA & $(0.8,1.0,1.0)$ & $(0.8,1.0,1.0)$ & $(0.8,1.0,1.0)$ & $(0.8,1.0,1.0)$ & $(0.0,0.0,0.2)$ & $(0.0,0.0,0.2)$ & $(3.2,4 \cdot 0,4.4)$ & 3,866 & 10 \\
\hline YUNANISTAN & $(0.6,0.8,1.0)$ & $(0.4,0.6,0.8)$ & $(0.4,0.6,0.8)$ & $(0.6,0.8,1.0)$ & $(0.0,0.0,0.2)$ & $(0.0,0.0,0.2)$ & $(2.0,2.8,4.0)$ & 2,933 & 18 \\
\hline MACARISTAN & $(0.6,0.8,1.0)$ & $(0.4,0.6,0.8)$ & $(0.4,0.6,0.8)$ & $(0.2,0.4,0.6)$ & $(0.6,0.8,1.0)$ & $(0.6,0.8,1.0)$ & $(2.8,4.0,5.2)$ & 4,000 & 7 \\
\hline İRLANDA & $(0.6,0.8,1.0)$ & $(0.6,0.8,1.0)$ & $(0.6,0.8,1.0)$ & $(0.0,0.0,0.2)$ & $(0.6,0.8,1.0)$ & $(0.6,0.8,1.0)$ & $(3 \cdot 0,4 \cdot 0,5 \cdot 2)$ & 4,066 & 5 \\
\hline ITALYA & $(0.6,0.8,1.0)$ & $(0.4,0.6,0.8)$ & $(0.8,1.0,1.0)$ & $(0.6,0.8,1.0)$ & $(0.2,0.4,0.6)$ & $(0.0,0.0,0.2)$ & $(2.6,3.6,4.6)$ & 3,600 & 13 \\
\hline LETONYA & $(0.0,0.0,0.2)$ & $(0.2,0.4,0.6)$ & $(0.0,0.0,0.2)$ & $(0.0,0.0,0.2)$ & $(0.8,1.0,1.0)$ & $(0.8,1.0,1.0)$ & $(1.8,2.4,3.2)$ & 2,466 & 22 \\
\hline LITVANYA & $(0.2,0.4,0.6)$ & $(0.2,0.4,0.6)$ & $(0.2,0.4,0.6)$ & $(0.0,0.0,0.2)$ & $(0.6,0.8,1.0)$ & $(0.6,0.8,1.0)$ & $(1.8,2.8,4.0)$ & 2,866 & 19 \\
\hline LÜKSEMBURG & $(0.4,0.6,0.8)$ & $(0.6,0.8,1.0)$ & $(0.6,0.8,1.0)$ & $(0.2,0.4,0.6)$ & $(0.4,0.6,0.8)$ & $(0.4,0.6,0.8)$ & $(2.6,3.8,5.0)$ & 3,800 & 11 \\
\hline MALTA & $(0.8,1.0,1.0)$ & $(0.6,0.8,1.0)$ & $(0.8,1.0,1.0)$ & $(0.8,1.0,1.0)$ & $(0.0,0.0,0.2)$ & $(0.0,0.0,0.2)$ & $(3.0,3.8,4.4)$ & $3, / 33$ & 12 \\
\hline HOLLANDA & $(0.6,0.8,1.0)$ & $(0.6,0.8,1.0)$ & $(0.6,0.8,1.0)$ & $(0.8,1.0,1.0)$ & $(0.0,0.0,0.2)$ & $(0.0,0.0,0.2)$ & $(2.6,3.4,4.4)$ & 3,466 & 15 \\
\hline POLONYA & $(0.0,0.0,0.2)$ & $(0.0,0.0,0.2)$ & $(0.0,0.0,0.2)$ & $(0.0,0.0,0.2)$ & $(0.4,0.6,0.8)$ & $(0.4,0.6,0.8)$ & $(0.8,1.2,2.4)$ & 1,466 & 30 \\
\hline PORTEKIZ & $(0.0,0.0,0.2)$ & $(0.2,0.4,0.6)$ & $(0.0,0.0,0.2)$ & $(0.0,0.0,0.2)$ & $(0.8,1.0,1.0)$ & $(0.8,1.0,1.0)$ & $(1.8,2.4,3.2)$ & 2,466 & 22 \\
\hline ROMANYA & $(0.2,0.4,0.6)$ & $(0.0,0.0,0.2)$ & $(0.2,0.4,0.6)$ & $(0.4,0.6,0.8)$ & $(0.2,0.4,0.6)$ & $(0.2,0.4,0.6)$ & $(1.2,2.2,3.4)$ & 2,266 & 25 \\
\hline SLOVAKYA & $(0.6,0.8,1.0)$ & $(0.4,0.6,0.8)$ & $(0.6,0.8,1.0)$ & $(0.4,0.6,0.8)$ & $(0.4,0.6,0.8)$ & $(0.4,0.6,0.8)$ & $(2.8,4.0,5.2)$ & 4,000 & 7 \\
\hline SLOVENYA & $(0.2,0.4,0.6)$ & $(0.2,0.4,0.6)$ & $(0.2,0.4,0.6)$ & $(0.4,0.6,0.8)$ & $(0.2,0.4,0.6)$ & $(0.0,0.0,0.2)$ & $(1.2,2.2,3.4)$ & 2,266 & 25 \\
\hline ISPANYA & $(0.2,0.4,0.6)$ & $(0.4,0.6,0.8)$ & $(0.2,0.4,0.6)$ & $(0.0,0.0,0.2)$ & $(0.6,0.8,1.0)$ & $(0.6,0.8,1.0)$ & $(2 \cdot 0,3 \cdot 0,4.2)$ & 3,066 & 17 \\
\hline ISVEÇ & $(0.4,0.6,0.8)$ & $(0.8,1.0,1.0)$ & $(0.6,0.8,1.0)$ & $(0.0,0.0,0.2)$ & $(0.8,1.0,1.0)$ & $(0.8,1.0,1.0)$ & $(3.4,4.4,5.0)$ & 4,266 & 4 \\
\hline $\begin{array}{l}\text { BIRLEŞIK } \\
\text { KRALLIK }\end{array}$ & 1.0) & $(0.6,0.8,1.0)$ & $(0.6,0.8,1.0)$ & $(0.0,0.0,0.2)$ & $(0.6,0.8,1.0)$ & $(0.6,0.8,1.0)$ & $(3.0,4.0,5.2)$ & 4,066 & 5 \\
\hline TÜRKIYE & $(0.0,0.0,0.2)$ & $.0,0.0,0.2)$ & $(0.0,0.0,0.2)$ & $(0.2,0.4,0.6)$ & $(0.2,0.4,0.6)$ & $(0.2,0.4,0.6)$ & $(0.6,1.2,2.4)$ & 1,400 & 31 \\
\hline MAKEDONYA & $(0.0,0.0,0.2)$ & $(0.0,0.0,0.2)$ & $(0.0,0.0,0.2)$ & $(0.4,0.6,0.8)$ & $(0.2,0.4,0.6)$ & $(0.2,0.4,0.6)$ & $(0.8,1.4,2.6)$ & 1,600 & 28 \\
\hline ARNAVUTLUK & $(0.0,0.0,0.2)$ & $(0.0,0.0,0.2)$ & $(0.0,0.0,0.2)$ & $(0.2,0.4,0.6)$ & $(0.2,0.4,0.6)$ & $(0.2,0.4,0.6)$ & $(0.6,1.2,2.4)$ & 1,400 & 31 \\
\hline SIRBISTAN & $(0.2,0.4,0.6)$ & $(0.0,0.0,0.2)$ & $(0.2,0.4,0.6)$ & $(0.8,1.0,1.0)$ & $(0.0,0.0,0.2)$ & $(0.0,0.0,0.2)$ & $(1.2,1.8,2.8)$ & 1,933 & 27 \\
\hline BOSNA HERSEK & $(0.0,0.0,0.2)$ & $(0.0,0.0,0.2)$ & $(0.0,0.0,0.2)$ & $(0.6,0.8,1.0)$ & $(0.0,0.0,0.2)$ & $(0.0,0.0,0.2)$ & $(0.6,0.8,2.0)$ & 1,133 & 34 \\
\hline KARA & (0. & $(0.0,0.0,0.2)$ & $(0.0,0.0,0.2)$ & $(0.2$, & $(0.2,0$ & $0.6)$ & $(0.6$ & 1,400 & 31 \\
\hline
\end{tabular}

Tablo 9'da görüldüğü gibi durulaştırımış değerler 6 farklı modelin sonuçlarının bütünleştirildiği performans puanları göstermektedir. Bütünleştirilen sonuçlara göre çevresel performansı en iyi olan ülkenin Avusturya olduğu, Danimarka ve Fransa'nın puanlarının eşit olarak Avusturya'yı takip ettiği, İsveç ve Birleşik Krallığın ise 4. ve 5. sıralarda olduğu görülmektedir. Performans düzeyi en az olan ülkeler ise Bosna Hersek, Karadağ, Arnavutluk, Türkiye ve Polonya olarak belirlenmiştir. 


\section{Sonuç ve Öneriler}

Son yıllarda çevre konusunda farkındalığın artmasıyla beraber tüm ülkeler çevresel sorunlarını çözmek amacıyla çeşitli politikalar geliştirilmektedir. Bu politikaların etkinliğinin değerlendirilebilmesi ve ülkelerin diğer ülkeler arasındaki durumunu görebilmesi için düzenli olarak performans değerlendirilmesi önemli bir konudur. Bu çalışmada ülkelerin çevresel performanslarının ölçümünde Entropi, GiA ve MOORA yöntemleri kullanılarak 6 farklı ÇKKV modeli geliştirilmiştir. Daha sonra bu 6 farklı modelin sonucu bulanık mantık tabanlı bir yaklaşım ile bütünleştirilmiştir. Entropi yöntemi kriterlerin ağılıklandırılmasında, GiA ve MOORA yöntemleri de ülkelerin performanslarının belirlenmesinde ve sıralanmasında kullanılmıştır. Entropi yöntemine göre en önemli kriterin ormanlar, tarım, su kaynakları, hava kirliği ve balıkçılık değişkenleri olduğu, en az öneme sahip kriterlerin ise hava kalitesi, su kalitesi ve ağır metaller değişkeni olduğu belirlenmiştir. GiA yöntemi kullanılarak Entropi-GiA ve kriterleri eşit ağırlıklı GiA olmak üzere iki yöntem ele alınmıştır. Entropi-GiA yöntemine göre performansı en iyi olan ülkeler Malta, Avusturya ve Fransa iken, kriterleri eşit ağırlıklı GiA yöntemine göre Fransa, Avusturya ve Almanya'dır. MOORA yöntemi kullanılarak da kriterleri eşit ağırlıklı MOORA Oran yaklaşımı, Entropi-MOORA Önem Katsayısı yaklaşımı, kriterleri eşit ağırlıklı MOORA Referans Nokta yaklaşımı ve Entropi-MOORA Referans Nokta Yaklaşımı olmak üzere 4 farklı yöntem ile çözüm aranmıştır. Bu yöntemlere göre, Avusturya, Fransa, Malta, Almanya, Bosna Hersek ve Sırbistan en iyi çevresel performansa sahiptirler. Son olarak ise bulanık mantık tabanlı yaklaşım ile bütünleştirilen sonuçlara göre performansı en iyi ülkeler Avusturya, Danimarka, Fransa, İsveç ve Birleşik Krallık; performans düzeyi en az olan ülkeler ise Bosna Hersek, Karadağ, Arnavutluk, Türkiye ve Polonya olarak tespit edilmiştir. Çalışma kapsamında önerilen modelin sonuçlarının çevre performans indeksi 2018 sonuçları ile karşılaştırılabilmesi için öncelikle çevresel performans indeksi sonuçları ve ülke sıralamaları Tablo 10'da gösterilmiştir.

Tablo 10: Çevresel Performans Indeksi 2018 Sonuçları

\begin{tabular}{lclc}
\hline ÜLKELER & Endeks Değeri (Sıralama) & ÜLKELER & Endeks Değeri (Sıralama) \\
\hline AVUSTURYA & $78,970(7)$ & LÜKSEMBURG & $79,120(6)$ \\
BELÇIKA & $77,380(12)$ & MALTA & $80,900(3)$ \\
BULGARISTAN & $67,850(20)$ & HOLLANDA & $75,460(14)$ \\
HIRVATiSTAN & $65,450(25)$ & POLONYA & $64,110(29)$ \\
KIBRIS & $72,600(16)$ & PORTEKiz & $71,910(17)$ \\
ÇEK CUMHURIYETi & $67,680(21)$ & ROMANYA & $64,780(27)$ \\
DANIMARKA & $81,600(2)$ & SLOVAKYA & $70,600(18)$ \\
ESTONYA & $64,310(28)$ & SLOVENYA & $67,570(22)$ \\
FiNLANDIYA & $78,640(9)$ & iSPANYA & $78,390(10)$ \\
FRANSA & $83,950(1)$ & iSVEÇ & $80,510(4)$ \\
ALMANYA & $78,370(11)$ & BiRLEŞiK KRALLIK & $79,890(5)$ \\
YUNANiSTAN & $73,600(15)$ & TÜRKiYE & $52,960(33)$ \\
MACARISTAN & $65,010(26)$ & MAKEDONYA & $61,060(31)$ \\
IRLANDA & $78,770(8)$ & ARNAVUTLUK & $65,460(24)$ \\
ITALYA & $76,960(13)$ & SIRBiSTAN & $57,490(32)$ \\
LETONYA & $66,120(23)$ & BOSNA HERSEK & $41,840(34)$ \\
LiTVANYA & $69,330(19)$ & KARADAĞ & $61,330(30)$ \\
\hline
\end{tabular}


Tablo 10 incelendiğinde, performansı en iyi ülkelerin Fransa, Danimarka, Malta, İsveç ve Birleşik Krallık olduğu, performansı en düşük olan ülkelerin ise Karadağ, Makedonya, Sırbistan, Türkiye ve Bosna Hersek olduğu görülmektedir. Çalışma kapsamında geliştirilen modelde ise performansı en iyi ülkeler Avusturya, Danimarka, Fransa, İsveç ve Birleşik Krallık'dır. Performans düzeyi en az olan ülkeler ise Bosna Hersek, Karadağ, Arnavutluk, Türkiye ve Polonya olarak belirlenmiştir. Sonuçları karşılaştırmalı olarak incelemek ve sıralamalar arası farklılığı test etmek amacıyla Wilcoxon testi yapılmış olup, Tablo 11'de sonuçlara yer verilmiştir.

Tablo 11: Çevresel Performans Indeksi ile Geliştirilen Model Arasındaki Sonuçların Farklılık Analizi

\begin{tabular}{|c|c|c|c|c|c|c|}
\hline \multirow{6}{*}{ Bulanık Model - EPI 2018} & & & Ortalama & Sıralar & & \\
\hline & Siralar & $\mathrm{N}$ & Sıra & Toplamı & Z & $\mathrm{P}$ \\
\hline & Negatif Sıralar & 34 & 17,5 & 595 & $-5,086$ & ,000 \\
\hline & Pozitif Sıralar & 0 & 0 & 0 & & \\
\hline & Eşitlik & 0 & 0 & 0 & & \\
\hline & Toplam Değer & 34 & & & & \\
\hline
\end{tabular}

Tablo 11 incelendiğinde, $p=0,000$ değeri 0.05 'ten küçük olduğundan, istatistiksel olarak anlamlı farklılık olduğu görülmektedir. Çalışma kapsamında geliştirilen modelin sonuçlarının çevresel performans indeksi raporları sonuçlarından farklı olduğu tespit edilmiştir.

Çalışma kapsamında uygulanan 6 farklı çok kriterli karar verme yöntemi ile elde edilen sonuçları, bulanık mantık tabanlı yaklaşıma göre elde edilen sonuç ile kıyaslamak amacıyla Wilcoxon testi uygulanmıştır. Test sonuçları Tablo 12'de gösterilmiştir.

Tablo 12: ÇKKV Yöntemleri Sonuçları ile Geliştirilen Model Arasındaki Sonuçların Farklılık Analizi

\begin{tabular}{|c|c|c|c|c|c|c|}
\hline \multicolumn{7}{|l|}{ Modeller } \\
\hline & & & Ortalama & Sıralar & & \\
\hline & Sıralar & $\mathrm{N}$ & Sira & Toplamı & Z & $\mathrm{P}$ \\
\hline \multirow{4}{*}{ Bulanık Mantık - Entropi+GiA } & Negatif Sıralar & 0 & 0 & 0 & \multirow{4}{*}{$-5,086$} & \multirow{4}{*}{0,000} \\
\hline & Pozitif Sıralar & 34 & 17,5 & 595 & & \\
\hline & Eşitlik & 0 & & & & \\
\hline & Toplam Değer & 34 & & & & \\
\hline \multirow{4}{*}{ Bulanık Mantık - Eşit Önem GiA } & Negatif Sıralar & 0 & 0 & 0 & \multirow{4}{*}{$-5,086$} & \multirow{4}{*}{0,000} \\
\hline & Pozitif Sıralar & 34 & 17,5 & 595 & & \\
\hline & Eşitlik & 0 & & & & \\
\hline & Toplam Değer & 34 & & & & \\
\hline \multirow{4}{*}{ Bulanık Mantık - MOORA Oran } & Negatif Sıralar & 3 & 3,67 & 11 & \multirow{4}{*}{$-4,898$} & \multirow{4}{*}{0,000} \\
\hline & Pozitif Sıralar & 31 & 18,84 & 584 & & \\
\hline & Eşitlik & 0 & & & & \\
\hline & Toplam Değer & 34 & & & & \\
\hline \multirow{4}{*}{ Bulanık Mantık - Entropi+MOORA } & Negatif Sıralar & 0 & 0 & 0 & \multirow{4}{*}{$-5,086$} & \multirow{4}{*}{0,000} \\
\hline & Pozitif Sıralar & 34 & 17,5 & 595 & & \\
\hline & Eşitlik & 0 & & & & \\
\hline & Toplam Değer & 34 & & & & \\
\hline
\end{tabular}


Tablo 12. ÇKKV Yöntemleri Sonuçları ile Geliştirilen Model Arasındaki Sonuçların Farklıık

\begin{tabular}{llrrrrr}
\multicolumn{6}{c}{ Analizi (devamı) } \\
\hline \multirow{2}{*}{ Bulanık Mantık - Eşit Önem MOORA } & Negatif Sıralar & 0 & 0 & 0 & & \\
& Pozitif Sıralar & 34 & 17,5 & 595 & $-5,086$ & 0,000 \\
& Eşitlik & 0 & & & & \\
& Toplam Değer & 34 & & & & \\
\hline Bulanık Mantık - Entropi+MOORA & Negatif Sıralar & 0 & 0 & 0 & \\
Referans & Pozitif Sıralar & 34 & 17,5 & 595 & $-5,086$ & 0,000 \\
& Eşitlik & 0 & & & & \\
& Toplam Değer & 34 & & & & \\
\hline
\end{tabular}

Tablo 12 ' de yer alan test sonuçlarına göre, tüm $p$ değerleri $(p=0,000), 0.05$ 'ten küçük olduğundan istatistiksel olarak anlamlı farklııklar tespit edilmiştir. Çalışma kapsamında geliştirilen bulanık mantık tabanlı modelin sonuçları ile 6 farklı çok kriterli karar verme yöntemlerinin sonuçlarının birbirinden farklı olduğu gözlemlenmiştir.

Çalışmanın veri setini oluştururken yararlanılan çevresel performans indeksi ağırlıklı ortalama yöntemi ile basit düzeyde bir çözüm sunmaktayken; bu çalışma ile ÇKKV teknikleri ve önerilen bulanık mantık tabanlı yaklaşım kullanılarak daha kapsamlı bir metodoloji sunulmuştur. Son aşamada yararlanılan bulanık mantık tabanlı bir yaklaşım ile tüm sonuçların bütünleştirilebileceği önerilmiştir. Ayrıca önerilen modelin karşılaştırılan diğer ÇKKV yöntemleri ve çevresel performans indeksi sonuçları ile farklılıkları istatistiksel olarak test edilmiştir. İleride yapılacak çalışmalarda farklı ÇKKV teknikleri ile çevresel performans ölçümü yapılarak elde edilen sonuçlar önerilen bulanık mantık tabanlı yaklaşım ile bütünleştirilebilir ve bu çalışmanın sonuçları ile karşılaştırılabilir. Bununla birlikte bu çalışmada kullanılan ÇKKV modelleri proje seçimi, tedarikçi değerlendirme, yer seçimi, personel seçimi vb. birçok alanda uygulanabilir ve önerilen bulanık mantık yaklaşımı birden fazla ÇKKV yöntemi kullanılan problemlerde tek bir sonuç elde edilebilmesi için kullanılabilir. 


\section{Kaynaklar}

Ab-rahim, Rossazana (2015), "Environmental Performance of ASEAN Countries: A Data Envelopment Analysis", Journal of Economic Policy and Research, Vol. 10, No. 1: 98-108.

Adalı, Esra Aytaç; Tuş Işık, Ayşegül (2017), "The Multi-Objective Decision Making Methods Based on MULTIMOORA and MOOSRA For The Laptop Selection Problem, Journal of Industrial Engineering International, Vol. 13, No. 2: 229-237.

Akıncı, Sevcan Kılıç; Akıncı, M. Mehmet (2010), "Sürdürülebilir Kalkınmaya Katkı Bağlamında Örgütlerin Çevresel Performansları ve Performans Değerlendirme Teknikleri", Atatürk Üniversitesi iktisadi ve Idari Bilimler Dergisi, C. 24, S. 1: 193-207.

Aksu, Esra Özkan; Gencer, Cevriye Temel (2018), "Veri Zarflama Analizi İle OECD Ülkelerinin Çevre Performansının Incelenmesi", International Journal of Economic and Administrative Studies, 18. EYi Özel Sayısı, 191-206.

Bhowmik, Chiranjib; Baruah, Abhinandan; Bhowmik, S.; Ray, A. (2009), “Green Energy Sources Selection For Sustainable Energy Planning Using Multi-Criteria Decision-Making Approach", International Conference on Mechanical, Materials and Renewable Energy, Vol. 377, No. 1: 1-9.

Bimha, Alfred; Nhamo, Goldwell (2017), “Measuring Environmental Performance of Banks: Evidence From Carbon Disclosure Project (CDP) Reporting Banks", Journal of Economic and Financial Sciences, Vol. 10, No. 1: 26-46.

Brauers, Willem Karel (2013), "Multi-Objective Seaport Planning by MOORA Decision Making”, Annals of Operations Research, Vol. 206, No. 1: 39-58.

Brauers, Willem Karel; Ginevičius, Romualdas; Podvezko, V. (2010), "Regional Development In Lithuania Considering Multiple Objectives By The MOORA Method", Technological and Economic Development of Economy, Vol. 16, No. 4: 613-640.

Brauers, Willem Karel; Ginevicius, Romualdas (2009), "Robustness in Regional Development Studies: The Case of Lithuania", Journal of Business Economics and Management, Vol. 10, No. 2: 121-140.

Brauers, Willem Karel; Zavadskas, Edmundas Kazimieras (2006), "The MOORA Method and its Application to Privatization in a Transition Economy", Control and Cybernetic, Vol. 35, No. 2: 445-469.

Brauers, Willem Karel; Zavadskas, Edmundas Kazimieras; Turskis, Z.; Vilutiene, T. (2008), "Multi-objective Contractor's Ranking by Applying the Moora Method", Journal of Business Economics and Management, Vol. 9, No. 4: 245255.

Campos, Lucila M.S; Heizen, Daiane Aparecida de Melo, Verdinelli, M. A.; Miguel, P. A. C. (2015), "Environmental Performance Indicators: A Study on ISO 14001 Certified Companies", Journal of Cleaner Production, Vol. 99: 286296.

Chang, Young-Tae (2013), "Environmental Efficiency of Ports: A Data Envelopment Analysis Approach", Maritime Policy \& Management, Vol. 40, No. 5: 467-478.

Dashore, Kshitij; Pawar, Shashang Sing; Sohani, N.; Verma, D. S. (2013), “Product Evaluation Using Entropy and Multi Criteria Decision Making Methods", International Journal of Engineering Trends and Technology, Vol. 4, No. 5: 2183-2187.

Demircioğlu, Mert; Coşkun, İbrahim Tolga (2018), "Critic-Moosra Yöntemi ve UPS Seçimi Üzerine Bir Uygulama”, Çukurova Üniversitesi Sosyal Bilimler Enstitüsü Dergisi, C. 27, S. 1: 183-195.

Deng, Julong (1989), "Introduction to Grey System Theory", The Journal of Grey System, Vol. 1, No. 1: 1-24.

Diakoulaki, Danae; Mavrotas, George; Papayannakis, L. (1995), “Determining Objective Weights in Multiple Criteria Problems: The CRITIC Method", Computers \& Operations Research, Vol. 22, No. 7: 763-770.

Djoundourian, Salpie (2012), "Environmental Performance of Developing Countries: A Comparative Study", Topics in Middle Eastern and African Economies, Vol. 14: 265-277.

Dwivedi, Sanjay Kumar; Dwivedi, Ashutosh (2018), “Application of MOORA And WSM Method For Supplier Selection In Manufacturing", International Journal of Advance Research and Development, Vol. 3, No. 7: 114-117.

Erol, İsmail; Ferrell Jr, William (2009), "Integrated Approach for Reorganizing Purchasing: Theory and a Case Analysis on a Turkish Company", Computers \& Industrial Engineering, Vol. 56, No. 4: 1192-1204.

Gadakh, Vijay S. (2011), "Application of MOORA Method For Parametric Optimization of Milling Process", International Journal Of Applied Engineering Research, Dindigul, Vol. 1, No. 4: 743-758.

García-Sánchez, Isabel Maria; Almeida, Thiago Alexandre das Neves; Camara, R .P. B. (2015), "A Proposal for A Composite Index of Environmental Performance (CIEP) for Countries", Ecological Indicators, Vol. 48: 171-188.

Gök, Murat; Yiğit, Sema (2017), "Türkiye'deki Büyükşehirlerin Sürdürülebilirlik Kriterleri Açısından İncelenmesi", Yönetim Bilimleri Dergisi, C. 15, S. 30: 253-273. 
Guo, Ji; Zhu, Dongdong; Wu, X.; Yan, Y. (2017), "Study on Environment Performance Evaluation and Regional Differences of Strictly-Environmental- Monitored Cities in China", Sustainability, Vol. 9, No. 12: 1-20.

Hasani, Hossein; Tabatabaei, Somayeh Akhavan; Amiri, G. (2012), "Grey Relational Analysis to Determine the Optimum Process Parameters for Open-End Spinning Yarns", Journal of Engineered Fibers and Fabrics, Vol. 7, No. 2: 81-86.

Hermann, Barbara; Kroeze, Carolen; Jawjit, W. (2006), “Assessing Environmental Performance by Combining Life Cycle Assessment, Multi-Criteria Analysis and Environmental Performance Indicators", Journal of Cleaner Production, Vol. 15, No. 18: 1787-1796.

Hourneaux Jr., Flavio; Hrdlicka, Hermann Atila; Gomes, C. M.; Kruglianskas, I. (2014), "The Use of Environmental Performance Indicators and Size Effect: A Study of Industrial Companies", Ecological Indicators, Vol. 36: 205-212.

Hsiao, Shih Wen; Lin, Hsing Hung; Ko, Y. C. (2017), "Application of Grey Relational Analysis to Decision-Making during Product Development", EURASIA Journal of Mathematics Science and Technology Education, Vol. 13, No. 6: 25812600.

Hsu, Chaug-Ing; Wen, Yuh-Horng (2000), "Application of Grey Theory and Multi Objective Programming towards Airline Network Design", European Journal of Operational Research, Vol. 127, No. 1: 44-68.

Hsu, Yu-Lung; Liu, Chun-Chu (2010). “Environmental Performance Evaluation and Strategy Management Using Balanced Scorecard", Environmental Monitoring and Assessment, Vol.170, No. 1-4: 599-607.

Ismail, Zubaidah; Tai, Jie Chuin; Kong, K. K.; Law, K. H.; Shirazi, S. M.; Karim, R. (2013), “Using Data Envelopment Analysis In Comparing The Environmental Performance and Technical Efficiency of Selected Companies In Their Global Petroleum Operation", Measurement, Vol. 46, No. 9: 3401-3413.

Jahan, Ali; Mustapha, Faizal; Sapuan, S. M.; Ismail, M. Y.; Bahraminasab, M. (2012), "A Framework for Weighting of Criteria in Ranking Stage of Material Selection Process", The International Journal of Advanced Manufacturing Technology, Vol. 58, No. 1: 411-420.

Kabak, Mehmet; Dağdeviren, Metin (2017), “A Hybrid Approach Based On ANP and Grey Relational Analysis For Machine Selection", Technical Gazette, Vol. 24, No. 1: 109-118.

Kundakçı, Nilsen. (2016), "Personnel Selection with Grey Relational Analysis", Management Science Letters, Vol. 6, No. 5: 351-360.

Kung, Chaang-Yung; Yan, Tzung-Ming; Chuang, S. C. (2006), "GRA to Assess the Operating Performance of Non-Life Insurance Companies in Taiwan", The Journal of Grey System, Vol. 18, No. 2: 155- 160.

Lee, Ming-Chang; Chang, Jui-Fang; Chen, J. F. (2011), “An Entropy Decision Model for Selection of Enterprise Resource Planning System", International Journal of Computer Trends and Technology, March to April Issue, 1-9.

Lin, Jiang-Long; Lin, C. L. (2005), "The Use of Grey-Fuzzy Logic for the Optimization of the Manufacturing Process", Journal of Materials Processing Technology, Vol. 160, No. 1: 9-14.

Liu, Wei; Tian, Jinping; Chen, L.; Lu, W.; Gao, Y. (2015), "Environmental Performance Analysis of Eco-Industrial Parks in China A Data Envelopment Analysis Approach", Journal of Industrial Ecology, Vol. 19, No. 6: 1070-1081.

Lundberg, Kristina; Balfors, Berit Brokking; Folkeson, L. (2009), "Framework for Environmental Performance Measurement In A Swedish Public Sector Organization", Journal of Cleaner Production, Vol. 17, No. 11: 10171024.

Metcalf, Kim R.; Woodall, W. Robert; Hobson, C. M.; Williams, P. L. (1996), “Environmental Performance Measurement: A Case Study", Environmental Quality Management, Vol. 6, No. 1: 27-37.

Moghimi, Masoomeh; Yazdi, Mohammadreza Taghizadeh (2016), “Applying Multi-Criteria Decision-Making (MCDM) Methods for Economic Ranking of Tehran-22 Districts to Establish Financial and Commercial Centers (Case: City of Tehran)", Urban Economics and Management, Vol. 5, No. 4: 43-55.

Myhre, Oddvar; Fjellheim, Kristin; Ringnes, H.; Reistad, T.; Longva, K. S.; Ramos, T. B. (2013), "Development of Environmental Performance Indicators Supported by An Environmental Information System: Application to the Norwegian Defence Sector", Ecological Indicators, 29, 293-306.

Nakıboğlu, Gülsün; Bulğurcu, Berna (2017), “işsletmelerin Çevresel Sürdürülebilirlik Göstergelerine Yönelik Farklı Bir Değerlendirme: Modifiye Edilmiş Dijital Mantık (MDL)", International Journal of Economic and Administrative Studies, UiK Özel Sayısı, 709-728.

Olafsson, Snjolfur; Cook, David; Davidsdottir, B.; Johannsdottir, L. (2014), “Measuring Countries' Environmental Sustainability Performance - A Review and Case Study of Iceland", Renewable and Sustainable Energy Reviews, Vol. 39: 934-948. 


\section{Eskişehir Osmangazi Üniversitesi IïB Dergisi}

Özbek, Aşır; Demirkol, İsa (2018), "Lojistik Sektöründe Faaliyet Gösteren İşletmelerin SWARA ve GíA Yöntemleri İle Analizi", Kırıkkale Üniversitesi Sosyal Bilimler Dergisi, C. 8, S. 1: 71-86.

Özdağoğlu, Aşkın, Yakut, Enis, Bahar, S. (2017), "Machine Selection in a Dairy Product Company with Entropy and SAW Method Integration”, Dokuz Eylül Üniversitesi Iktisadi ve Idari Bilimler Fakültesi Dergisi, C. 32, S. 1: 341-359.

Peker, İskender; Baki, Birdoğan (2011), “Gri İlişkisel Analiz Yöntemiyle Türk Sigortacılık Sektöründe Performans Ölçümü", International Journal of Economic and Administrative Studies, Vol. 4, No. 7: 1-18.

Sarkar, Asis; Panja, S. C., Das, D; Sarkar, B. (2015), "Developing an Efficient Decision Support System for NonTraditional Machine Selection: An Application of MOORA and MOOSRA", Production \& Manufacturing Research, Vol. 3, No. 1: 324-342.

Sarı, E.B. (2017), "Endüstri İşletmelerinde Ar-Ge Projelerini Öncelik Sıralamasında Entropi Ağırlıklı Topsis Yöntemine Dayalı Çok Kriterli Bir Analiz, International Journal of Academic Value Studies, Vol. 3, No. 11: 159-170.

Shahmardan, Amin; Zadeh, Mohammad Hendijani (2013), "An Integrated Approach for Solving A MCDM Problem, Combination of Entropy Fuzzy and F-PROMETHEE Techniques", Journal of Industrial Engineering and Management, Vol. 6, No. 4: 1124-1138.

Şimşek, Ali; Çatır, Ozan; Ömürbek, N. (2015), "TOPSIS Ve MOORA Yöntemleri İle Tedarikçi Seçimi: Turizm Sektöründe Bir Uygulama", Balıkesir University The Journal of Social Sciences Institute, Vol. 18, No. 33: 133-161.

Şişman, Bilal; Eleren, Ali (2013), "En Uygun Otomobilin Gri İlişkisel Analiz ve Electre Yöntemleri ile Seçimi”, Süleyman Demirel Üniversitesi Iktisadi ve Idari Bilimler Fakültesi Dergisi, C. 18, S. 3: 411-429.

Ünlü, Ulaş; Yalçın, Neşe; Yağlı, İ. (2017), "Kurumsal Yönetim ve Firma Performansı: TOPSIS Yöntemi ile BiST 30 Firmaları Üzerine Bir Uygulama”, Dokuz Eylül Üniversitesi Sosyal Bilimler Enstitüsü Dergisi, C.19, S. 1: 63-81.

Tam, Vivian W.Y; Tam, C. M; Zeng, S. X.; Chan, K. K. (2006), "Environmental Performance Measurement Indicators in Construction", Building and Environment, Vol. 41: 164-173.

Tanç, Ahmet; Gümrah, Abdurrahman (2015), "Sürdürülebilirlik Raporlaması ve Çevresel Performans: Borsa İstanbul'da Bir Uygulama", İşletme Araştırmaları Dergisi, C. 7, S. 2: 258-273.

Tsai, Chih-Hung; Chang, Ching-Liang; Chen, L. (2003), “Applying Grey Relational Analysis to the Vendor Evaluation Model", International Journal of The Computer, The Internet and Management, Vol. 11, No. 3: 45-53.

Vujičić, Momcilo D.; Papić, Milos Z., Blagojević, M. D. (2017), “Comparative Analysis of Objective Techniques for Criteria Weighing in Two MCDM Methods on Example of an Air Conditioner Selection", Tehnika, Vol. 72, No. 3: 422-429.

Wang, Tien-Chin; Lee, Hsien-Da (2009), "Developing a Fuzzy TOPSIS Approach Based on Subjective Weights and Objective Weights", Expert Systems with Applications, Vol. 6, No. 5: 8980-8985.

Wu, Hsing-Hung (2002), "A Comparative Study of Using Grey Relational Analysis in Multiple Attribute Decision Making Problems", Quality Engineering, Vol. 15, No. 2: 209-217.

Yıldırım, Bahadır Fatih; Önder, Emrah (2015), “Çok Kriterli Karar Verme Yöntemleri”, 2. Baskı, Bursa: Dora Yayıncılık.

Zadeh, Nazanin Chaharmahali; Kazemi, Roohollah (2016), "The Environmental Performance Evaluation of Ahwaz Pipe Manufacturing Company within the Environmental Management System", International Journal of Pharmaceutical Research \& Allied Sciences, 2016, Vol. 5, No. 3: 413-436.

Zhai, Lian-Yin; Khoo, Li-Pheng; Zhong, Z. W. (2009), “Design Concept Evaluation in Product Development Using Rough Sets and Grey Relation Analysis", Expert Systems with Applications, Vol. 36, No. 3: 7072-7079.

Zhang, Hong; Gu, Chao-Lin; Gu, L. W.; Zhang, Y. (2011), "The Evaluation of Tourism Destination Competitiveness by TOPSIS \& Information Entropy-A Case in the Yangtze River Delta of China", Tourism Management, Vol. 32, No. 2: 443-451.

Zhang, Xianqi; Wang, Chenbo; Li, E.; Xu, C. (2014), “Assessment Model of Eco Environmental Vulnerability based on Improved Entropy Weight Method", The Scientific World Journal, 1-7.

Zuo, Xuan; Hua, Hui; Dong, Z.; Hao, C. (2017), "Environmental Performance Index at the Provincial Level for China 2006-2011", Ecological Indicators, Vol. 75: 48-56. 